\title{
Impact of the COVID-19 Event on Trip Intensity and Air Quality in Southern China
}

\author{
Shun Wan', Kangping Cui ${ }^{1 *}$, Ya-Fen Wang², Jhong-Lin Wu ${ }^{3,4 *}$, Wei-Syun Huang ${ }^{5}$, Kaijie Xu', \\ Jiajia Zhang ${ }^{1}$ \\ ${ }^{1}$ School of Resources and Environmental Engineering, Hefei University of Technology, Hefei 230009, China \\ ${ }^{2}$ Department of Environmental Engineering, Chung-Yuan Christian University, Taoyuan 32023, Taiwan \\ ${ }^{3}$ Environmental Resource and Management Research Center, National Cheng Kung University, Tainan 70101, Taiwan \\ ${ }^{4}$ Sustainable Environment Research Laboratories, National Cheng Kung University, Tainan 70101, Taiwan \\ ${ }^{5}$ Department of Atmospheric Sciences, National Central University, Taoyuan 32001, Taiwan
}

\begin{abstract}
The COVID-19 epidemic discovered and reported at the end of December 2019 and began spreading rapidly around the world. The impact of the COVID-19 event on the trip intensity, AQI (air quality index), and air pollutants, including PM 2.5 , $\mathrm{PM}_{10}, \mathrm{SO}_{2}, \mathrm{CO}, \mathrm{NO}_{2}$, and $\mathrm{O}_{3}$ in Shenzhen, Guangzhou, and Foshan (the so-called 'three cities') from January 12 to March 27, in 2019 and 2020, are compared and discussed. In 2020, the combined trip intensity in the three cities ranged between 0.73 and 5.54 and averaged 2.57, which was $28.4 \%$ lower than that in 2019. In terms of the combined AQIs for the three cities, from January 12 to March 26, 2020, the daily AQIs ranged between 21.0 and 121.3 and averaged 56.4, which was 16.0\% lower than that in 2019. The average AQIs in order were Guangzhou (57.5) > Foshan (54.1) > Shenzhen (44.1). In 2019 , the distribution proportions of the six AQI classes were $45.2 \%, 50.4 \%, 4.40 \%, 0 \%, 0 \%$, and $0 \%$, respectively, while those in 2020 were $62.7 \%, 37.3 \%, 0 \%, 0 \%, 0 \%$ and $0 \%$, respectively. For the combined data for the three cities, on the top five days with the highest AQIs during the epidemic period, the average concentrations of $\mathrm{PM}_{2.5}, \mathrm{PM}_{10}, \mathrm{SO}_{2}, \mathrm{CO}_{2} \mathrm{NO}_{2}$, and $\mathrm{O}_{3}$ were $76.4 \mu \mathrm{g} \mathrm{m}^{-3}, 113.4 \mu \mathrm{g} \mathrm{m}^{-3}, 5.14 \mathrm{ppb}, 0.88 \mathrm{ppm}, 36.5 \mathrm{ppb}$ and $55.5 \mathrm{ppb}$, which were $55.2 \%, 49.4 \%, 55.1 \%, 30.0 \%$, $45.1 \%$ and $15.5 \%$ lower than those during the non-epidemic period (from January 12 to March 27, 2017-2019). The above results revealed that the comprehensive strict epidemic prevention and control actions reduced trip intensity and improved the air quality significantly.
\end{abstract}

Keywords: COVID-19; Trip intensity; AQI; $\mathrm{PM}_{2.5} ; \mathrm{PM}_{10} ; \mathrm{SO}_{2} ; \mathrm{CO} ; \mathrm{NO}_{2} ; \mathrm{O}_{3}$.

\section{INTRODUCTION}

Since the economic reform in 1978, China's economy has been in a state of rapid development (Chan and Yao, 2008). China has become an important driving force for the world's economic development. China's rapid economic development is accompanied by increased energy demand and health problems caused by air pollution.

A series of consequences caused by air pollution problems have attracted the attention and research of all countries in the world. A large number of research results have proved the obvious impact of air pollution on people's health (Pope and Dochery, 2006; Cao et al., 2012; Heal et al., 2012; Pope and Dochery, 2013; Jin et al., 2017). In 1952, there was a

\footnotetext{
* Corresponding author.

E-mail address: cuikangping@163.com (Ka. Cui); z8406004@email.ncku.edu.tw (J.L.Wu)
}

two-day sulphate environmental incident in London that eventually killed about 12,000 people. $\mathrm{Hu}$ et al. (2015) studied the impact of $\mathrm{PM}_{2.5}$ on human health, pointing out that fine particles can increase the incidence of respiratory and cardiovascular diseases. $\mathrm{PM}_{10}$ levels have a significant impact on mortality from cardiovascular and respiratory diseases (Samet et al., 2000; Liang et al., 2016; Wang et al., 2018). Sulfur dioxide in the air accumulates in the body through human respiration and affects the respiratory system, causing respiratory diseases such as asthma (Xu et al., 2020b). It is a cause for concern because it plays an important role in the formation of ozone, particle pollution, smog and acid rain (Kyrkilis et al., 2007). The impact of air pollution on human health and the human living environment makes air quality a serious issue for the Chinese government and the public (Xu et al., 2020a; Zhang et al., 2020).

On December 31, 2019, the WHO issued a warning that an unknown infectious disease was spreading (Atri et al., 2020). On February 11, 2020, WHO officially named this epidemic as COVID-19 and explained that this epidemic 
belongs to coronavirus (Anderson et al., 2020). As of July 20,2020 , the total confirmed cases were $14,348,858$, and the cumulative number of deaths was 603,691 worldwide. Researchers point out that most patients have symptoms of breathlessness and lung infections (Bashir et al., 2020; Holshue et al., 2020; Perlman 2020). After the outbreak of the epidemic, the Chinese government immediately formulated effective prevention and control measures. On January 24, 2020, Guangdong Province launched first-level response measures for the prevention and control of the COVID-19 epidemic, including strengthening environmental improvements, carrying out traffic quarantines, etc. Due to the spread and epidemic of COVID-19, the industrial production, business activities and public transportation in China were severely affected. These processes are closely related to both generation and transportation of atmospheric pollutants. Therefore, in this study, the trip intensity and air quality index for Shenzhen, Guangzhou and Foshan in Guangdong Province were investigated and compared for the nonepidemic period and the epidemic control period to explore the impact of COVID-19 on trip intensity and air quality.

According to many previous studies, there is a profound relation between air quality and human health (Heal et al., 2012; Jin et al., 2017). In order to confront air pollution problems and to measure the impact of air quality on human health (Kyrkilis et al., 2007), the air quality indexes were generated and developed. The most practical and advanced indicator of air pollution is Air Quality Index (AQI) established by the Environment Pollution Administration (EPA). The AQI system is based on six pollutants, $\mathrm{NO}_{2}$ (nitrogen dioxide), $\mathrm{SO}_{2}$ (sulfur dioxide), $\mathrm{CO}$ (carbon monoxide), $\mathrm{O}_{3}$ (ozone), $\mathrm{PM}_{10}$ (coarse particulate matter) and $\mathrm{PM}_{2.5}$ (fine particulate matter) (Kyrkilis et al., 2007; Lee 2019).

In order to investigate the influence of the COVID-19 epidemic on trip intensity and air quality in Shenzhen, Guangzhou and Foshan cities, in Southern China, this study compared the concentrations of $\mathrm{PM}_{2.5}, \mathrm{PM}_{10}, \mathrm{SO}_{2}, \mathrm{NO}_{2}, \mathrm{CO}$ and $\mathrm{O}_{3}$ against trip intensity from January 12 to March 27, 2019-2020. Also, the differences in the distribution of the six AQI Classes between 2019 and 2020 were studied, and the five highest daily AQI and related indicatory air pollutants from January 12 to March 27, 2017-2020 were also discussed in this article.

\section{METHODS}

Three cities, Shenzhen $\left(22^{\circ} 32^{\prime} \mathrm{N}, 114^{\circ} 03^{\prime} \mathrm{E}\right)$ (east bank of the Pearl River), Guangzhou $\left(23^{\circ} 06^{\prime} \mathrm{N}, 113^{\circ} 15^{\prime} \mathrm{E}\right)$ (The Pearl River runs through Guangzhou) and Foshan $\left(23^{\circ} 02^{\prime} \mathrm{N}\right.$, $113^{\circ} 06^{\prime} \mathrm{E}$ ) (The Xijiang and Beijiang Rivers run through Foshan) are located in Guangdong Province (Fig. 1), in Southern China. Data was obtained for the period from January 12 to March 27, 2017-2020 in Shenzhen, Guangzhou, and Foshan cities. The PM mass concentrations (including daily $\mathrm{PM}_{2.5}$ and $\mathrm{PM}_{10}$ ) and gaseous pollutants (including daily $\mathrm{SO}_{2}, \mathrm{NO}_{2}, \mathrm{CO}$, and 8 hour-averaged $\mathrm{O}_{3}$ ) were obtained from the China air quality online monitoring and analysis platform (http://www.aqistudy.cn/). The trip intensity (the indexed results of the ratio of the traveling population to the city's inhabitants) were obtained from Baidu migration data (https://qianxi.baidu.com/).

From 2017-2020, in Shenzhen, the average temperature ranged from $5-27^{\circ} \mathrm{C}$ in January, in the range of $5-29^{\circ} \mathrm{C}$ in February and from $11-29^{\circ} \mathrm{C}$ in March. In Guangzhou, the average temperature ranged from 4 to $28^{\circ} \mathrm{C}$ in January, from 3 to $29^{\circ} \mathrm{C}$ in February, and from 8 to $29^{\circ} \mathrm{C}$ in March. In Foshan, the average temperature range of 4-28, 4-29 and $9-29^{\circ} \mathrm{C}$ in January, February, and March, respectively.

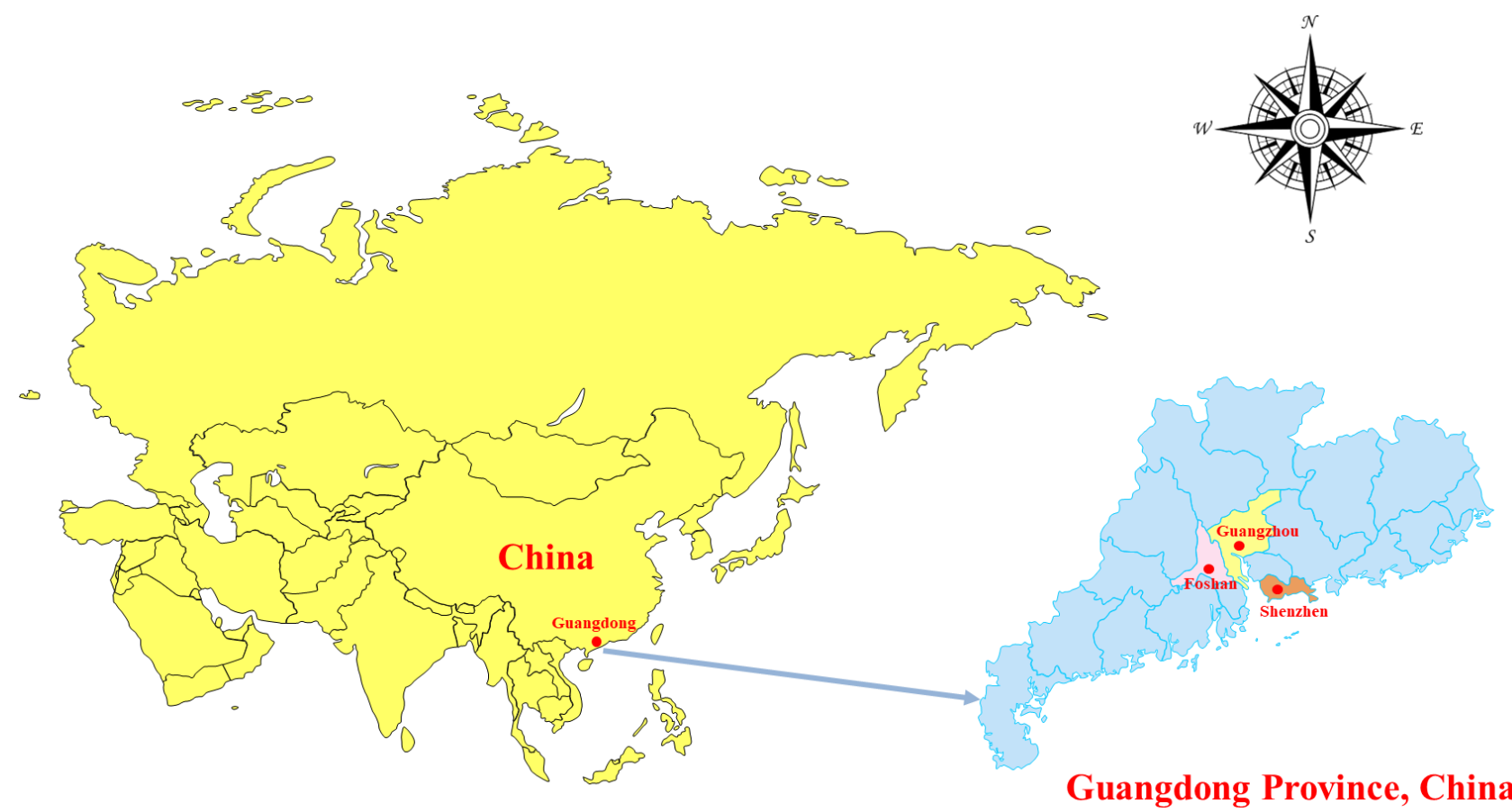

Fig. 1. Locations of Shenzhen, Guangzhou, and Foshan in Guangdong Province, China. 


\section{Air Quality Index (AQI)}

The sub-AQI of the six criteria pollutants were first calculated with the observation concentrations, as shown in Eq. (1) (She et al., 2017; Shen et al., 2017). The overall AQI represents the maximum of the sub-AQI of all pollutants, where when the AQI is higher than 50, the highest sub-AQI contributor is defined as the primary pollutant on that day, as shown in Eq. (2) (She et al., 2017; Shen et al., 2017):

$$
I A Q I_{P}=\frac{I_{\text {high }}-I_{\text {low }}}{C_{\text {high }}-C_{\text {low }}}\left(C_{P}-C_{\text {low }}\right)+I_{\text {low }}
$$

$A Q I=\max \left(I_{1}, I_{2}, \ldots, I_{n}\right)$

$I A Q I_{P}$ : the air quality sub index for air pollutant $p$. $C_{P}$ : the concentration of pollutant $p$.

$C_{\text {low }}$ : the concentration breakpoint that is $\leq C_{P}$.

$C_{\text {high }}$ : the concentration breakpoint that is $\geq C_{P}$.

$I_{\text {low }}$ : the index breakpoint corresponding to $C_{\text {low }}$.

$I_{\text {high }}$ : the index breakpoint corresponding to $C_{h i g h}$.

The daily AQIs were calculated based on the 24-hour average concentrations of $\mathrm{SO}_{2}, \mathrm{NO}_{2}, \mathrm{PM}_{2.5}, \mathrm{PM}_{10}, \mathrm{CO}$, and the daily average 8-hour maximum concentration of $\mathrm{O}_{3}$. From the United States Environmental Protection Agency (U.S. EPA) AQI, the ranges of AQI values related to air quality can be classified into six classes: Grade I: 0-50 (Good, Green), Grade II: 51-100 (Moderate, Yellow), Grade III: 101-150 (Unhealthy for Sensitive Groups; Orange), Grade IV: 151-200 (Unhealthy; Red), Grade V: 201-300 (Very unhealthy; Purple), and Grade VI: 300-500 (Hazardous; Maroon) (Hu et al., 2015; Lanzafame et al., 2015; She et al., 2017; Zhao et al., 2018).

\section{Wind Streamlines and Wind Speeds}

In order to understand the path of airflow in Guangdong Province from January to March in 2019 and 2020, respectively, we chose GrADS (Grid Analysis and Display System, http://cola.gmu.edu/grads/) to compute and draw the distribution of the monthly average near-surface streamlines and wind speed with NCEP GDAS/FNL 0.25 Degree Global Tropospheric Analyses data (https://rda.ucar.edu/dat asets/ds083.3/). During this period, the pathway of airflow is usually affected by the Siberia High (Siberia Anticyclone).

\section{RESULTS AND DISCUSSION}

\section{Comparison for Air Pollutants and Trip Intensity}

The daily trip intensity in Shenzhen, Guangzhou and Foshan from January 12 to March 27, 2019 and 2020, are shown in Fig. 2. The daily trip intensity and daily concentrations for $\mathrm{PM}_{2.5}, \mathrm{PM}_{10}, \mathrm{SO}_{2}, \mathrm{CO}, \mathrm{NO}_{2}$, and $\mathrm{O}_{3}$ from January 12 to March 27, 2019 and those for 2020, are shown and compared in Figs. 3(A)-3(F), respectively.

\section{Trip Intensity}

With the development of cloud database technology, the modeling and analysis of public big data plays an increasingly important role in epidemic warning, analysis and rapid response (Ajelli et al., 2010). In order to analyze and compare the changes in the trip intensity in Shenzhen, Guangzhou and Foshan during the epidemic control period, the daily trip intensity between January 12 and March 27, 2019 and those of 2020 for the three cities were shown in Fig. 2.

As shown in Fig. 2(a), in Shenzhen, from January 12 to March 27 in 2019, the trip intensity ranged between 0.94 and 4.61 , and averaged 3.45; the top five highest daily averages ranged from 4.38 to 4.54 and averaged 4.48 (from March 10-March 14, 2019), while the lowest five daily averages were between $0.94-1.00$ and averaged 0.97 (from February 4-February 8, 2019). However, in Shenzhen, from January 12 to March 26 in 2020, the trip intensity ranged between 0.73 and 4.97 and averaged 2.46, which was $28.8 \%$ lower than that in 2019. The top five highest daily average ranged from 4.46 to 4.97 and averaged 4.78 (from January 13-January 17, 2020), which was $6.7 \%$ higher than those in 2019. The lowest five daily average ranged between $0.73-$ 0.78 and averaged 0.76 (from January 26-January 30, 2020), which was $21.7 \%$ lower than that in 2019. As shown in Fig. 2 (a), the trip intensity in Shenzhen remained stable around its lowest point from February 4 to February 8, 2019. However, that in 2020 fell between January 25 and February 9, which was due to the comprehensive strict epidemic prevention and control actions taken in Guangdong Province, such as shutting down factories and traffic control. These actions greatly reduced the trip frequency.

As shown in Fig. 2(b), in Guangzhou, from January 12 to March 27 in 2019, the trip intensity ranged between 1.47 and 4.61, and averaged 3.57. The top five highest daily averages ranged from 4.35 to 4.59 and averaged 4.49 (from March 10-March 14, 2019), while the lowest five daily averages ranged between 1.47-1.64 and averaged 1.53 (during February 4-February 8, 2019). However, in Guangzhou, from January 12 to March 26 in 2020, the trip intensity ranged between 0.93 and 5.54, and averaged 2.48, which was $30.1 \%$ lower than that in 2019; the top five highest daily average ranged from 4.17 to 5.54 and averaged 4.67 (from January 13-January 17,2020 ), which was $4.0 \%$ higher than those in 2019 . The lowest five daily average ranged between $0.93-0.98$ and averaged 0.95 (from January 27-January 31 , 2020), which was $37.9 \%$ lower than those was in 2019. As shown in Fig. 2(b), the trip intensity in Guangzhou remained stable around its lowest point from February 4 to February 9,2019 . However, the lowest trip intensity in 2020 was between January 26 and February 9. As was the case with Shenzhen, the local traffic trip frequency in Guangzhou also was reduced due to the impact of strict control measures during the epidemic period.

As shown in Fig. 2(c), in Foshan, from January 12 to March 27 in 2019, the trip intensity ranged between 1.38 and 4.82 and averaged 3.74. The top five highest daily average ranged from 4.63 to 4.82 and averaged 4.72 (during March 10-March 14, 2019), while the lowest five daily average ranged between 1.38-1.63 and averaged 1.46 (during February 4-February 8, 2019). However, in Foshan, from January 12 to March 26 in 2020, the trip intensity ranged between 0.92 and 4.67 and averaged 2.77 , which was $25.9 \%$ lower than that in 2019. The top five highest daily averages ranged 


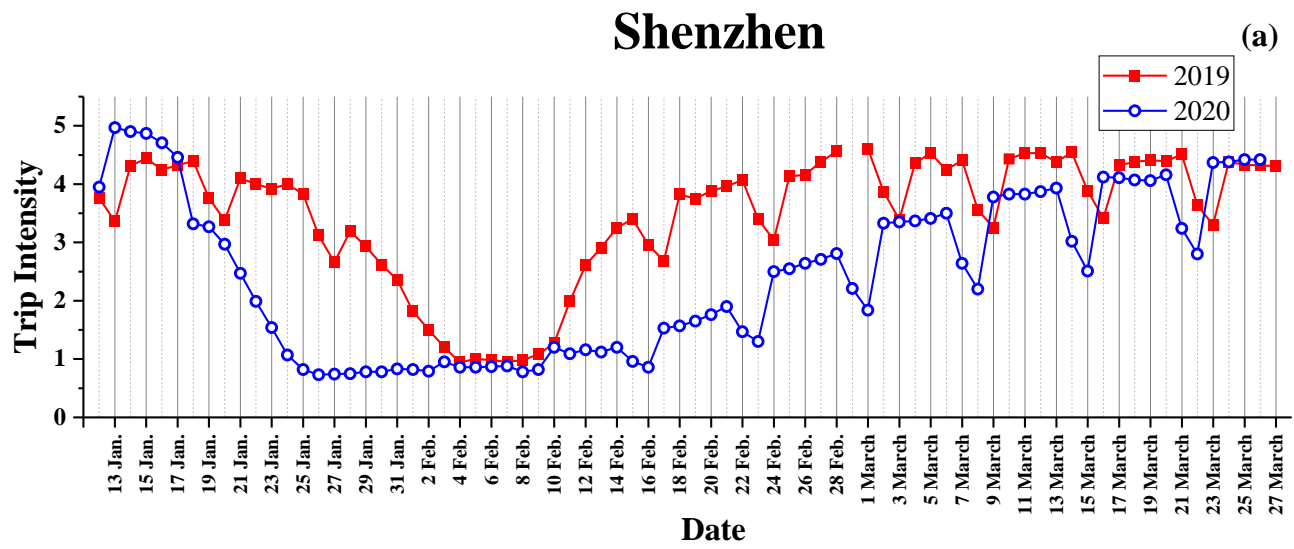

Guangzhou

(b)



Date

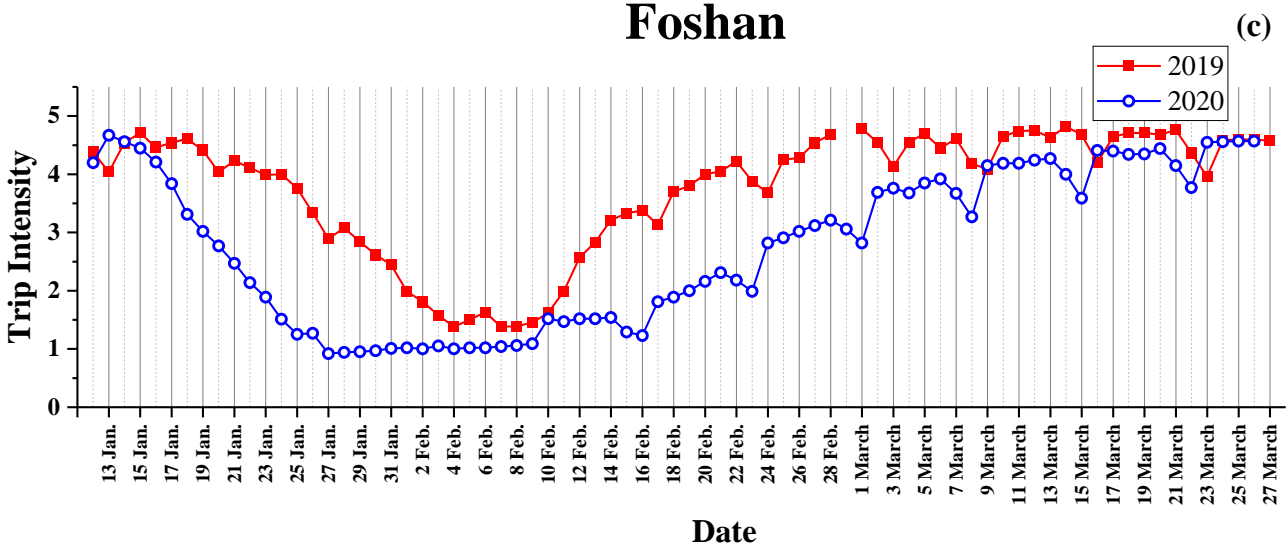

Fig. 2. The daily trip intensity of inhabitants in Shenzhen, Guangzhou, and Foshan from January 12 to March 27 , in 2019 and 2020 , respectively.

from 4.20 to 4.67 and averaged 4.42 (from January 12-January 16,2020 ), which was $6.4 \%$ lower than those in 2019 . The lowest five daily averages ranged between $0.92-1.01$ and averaged 0.96 (from January 27-January 31, 2020), which was $34.3 \%$ lower than those in 2019. As shown in Fig. 2(c), the trip intensity in Foshan remained stable around its lowest point from February 4 to February 9, 2019. However, the lowest trip intensity in 2020 was between January 27 and February 9, which was due to the restrictions measures resulting in a reduction in travel.

It can be seen that compared to the same period in 2019, the average trip intensity in the three cities decreased significantly. This indicated that strict prevention and control measures affected the travel plans of local residents. Also, the reduction in human travel activity may had impact on the atmospheric environment. Between January 12 and March 27, 2019 and the same period in 2020, the lowest values of trip intensity in the three cities all occurred during the Chinese New Year holiday. For the purpose of controlling the spread of COVID-19, China adopted self-quarantine for residents in the three cities, which caused the residents to cancel unnecessary trip plans, and in turn led the trip intensity to remain around its lowest point for about a week. After February 14, 2019 and 2020, the troughs in the trip intensity all occurred on a Sunday, which means that the impact of the holidays on people's travel activities was obvious. 


\section{PM2.5 Concentration}

$\mathrm{PM}_{2.5}$ is also known as fine particles, which refers to particles smaller than 2.5 micrometers in diameter. $\mathrm{PM}_{2.5}$ comes from production and daily combustion, including fuel vehicles, thermal power station, natural fires, agricultural combustion and some industrial processes (Kyrkilis et al., 2007). As an important component of aerosol, $\mathrm{PM}_{2.5}$ may affect the environment by changing the atmospheric radiation balance, reducing soil nutrient levels, lowering visibility, degrading ecosystem biodiversity and so on (Chen et al.,
2015; Myhre, 2009). Hu et al. (2015) studied the impact of $\mathrm{PM}_{2.5}$ on human health, pointing out that fine particles can induce cardiovascular and respiratory diseases in the body. The daily concentration of $\mathrm{PM}_{2.5}$ and trip intensity from January 12 to March 27, 2019 and those of 2020 are presented in Fig. 3(A), respectively.

As shown in Fig. 3(A), between January 12 and March 27, 2019, in Shenzhen, Guangzhou, and Foshan, the $\mathrm{PM}_{2.5}$ concentrations ranged between 11.0 and 74.0 , between 9.00 and 92.0 and between 10.0 and $81.0 \mu \mathrm{g} \mathrm{m}^{-3}$ and averaged
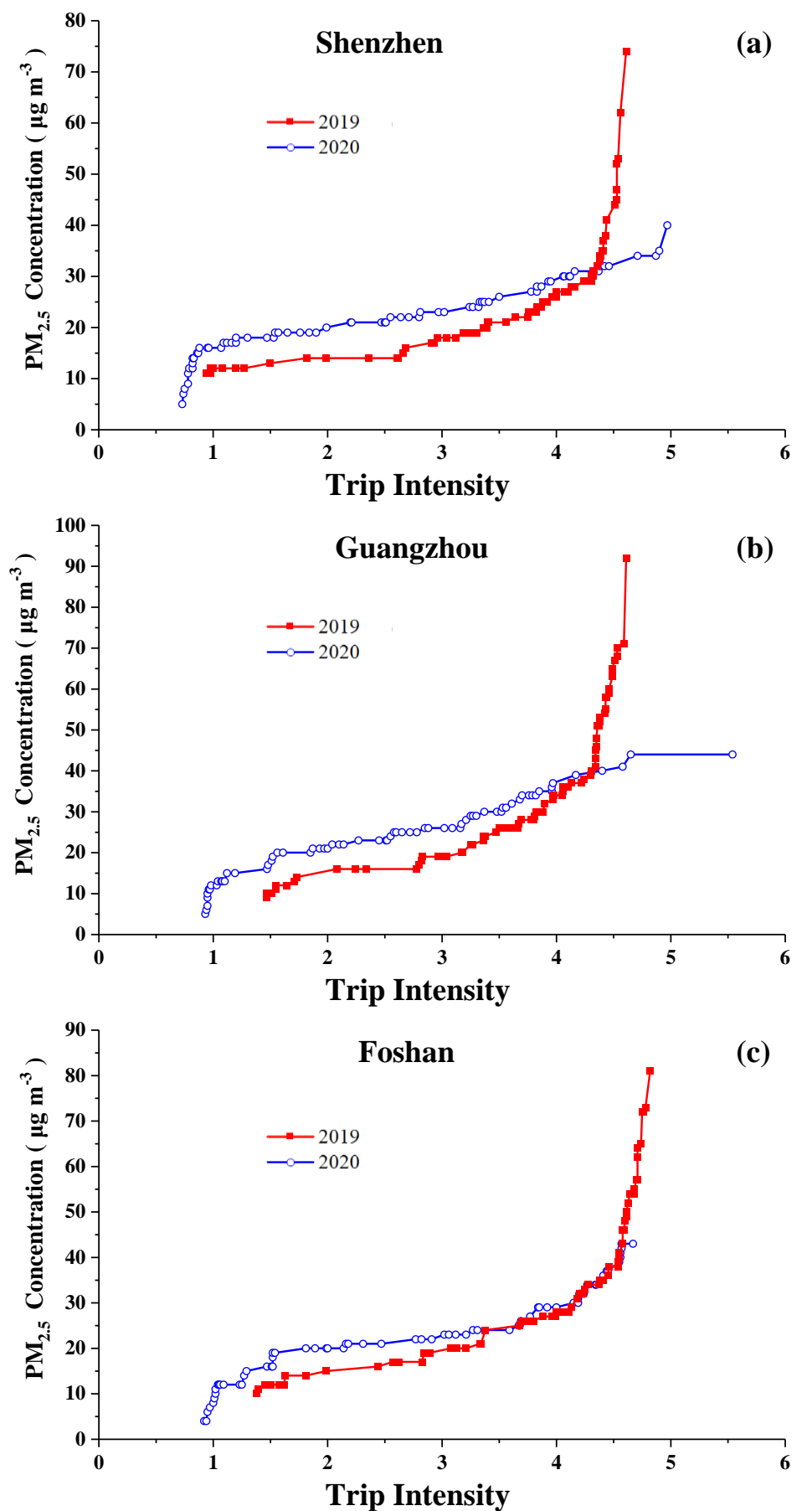

Fig. 3(A). The trip intensity and daily $\mathrm{PM}_{2.5}$ concentrations from January 12 to March 272019 and those in 2020 during the same period in Shenzhen, Guangzhou, and Foshan, respectively. 
25.9, 34.2, and $34.1 \mu^{-3} \mathrm{~g} \mathrm{~m}^{-3}$, respectively. Those during 2020 ranged from 5.00-40.0, 5.00-44.0, and 4.00-43.0 $\mathrm{\mu g} \mathrm{m}^{-3}$, and averaged $21.5,23.6$, and $22.9 \mu \mathrm{g} \mathrm{m}^{-3}$, respectively. These values in 2020 were $16.8 \%, 31 \%$, and $32.7 \%$ lower than those from January 12 to March 27, 2019. Based on the combined data from the three cities, from January 12 to March 26 2020, the average $\mathrm{PM}_{2.5}$ decreased by $27.7 \%$ compared with that during the same period in 2019. When the trip intensity of Shenzhen, Guangzhou, and Foshan were less than 4.4, 4.3 and 3.3, respectively, the $\mathrm{PM}_{2.5}$ concentrations corresponding to the same trip intensity were higher in 2020 than in 2019. Primary and secondary combustion products mainly come from motor vehicles and thermal power stations, which are two crucial sources of fine particles $\left(\mathrm{PM}_{2.5}\right)$. Therefore, this change was due to the fact that during the epidemic control period, while the trip intensity was reduced, the power plants continue normal operation and produced atmospheric pollutants.

It can be seen that compared with 2019, the concentration of $\mathrm{PM}_{2.5}$ decreased significantly from January 12 to March 26, 2020. There may be two reasons for this decline. The first reason is that January 24 is the traditional Chinese New Year, so a large number of factories are on holiday. This greatly reduces the industrial sources of $\mathrm{PM}_{2.5}$. The second, news about the COVID-19 epidemic gradually spread, and people canceled visits to go outside during the first lunar month. After entering February, the Chinese government announced a number of home segregation measures. This reduced the $\mathrm{PM}_{2.5}$ generation due to restrictions on transportation. In March, people took the initiative to avoid going out for self-protection, and factory operations resumed slowly, which means that the amounts of fine particles from motor vehicles and industrial production is greatly reduced. With the gradual reduction of industrial sources, the influence of trip intensity on $\mathrm{PM}_{2.5}$ concentration changes was therefore relatively greater.

\section{PM ${ }_{10}$ Concentration}

$\mathrm{PM}_{10}$ levels have a significant impact on mortality from cardiovascular and respiratory diseases (Samet et al., 2000; Liang et al., 2016; Wang et al., 2018). Researchers point out that atmospheric particulates carry acidic and toxic substances, including polycyclic aromatic hydrocarbons and heavy metals, which are believed to have an impact on human health (Song et al., 2008; Tao et al., 2009; Matus et al., 2012; Sun et al., 2014; Liang et al., 2016). The daily concentration of $\mathrm{PM}_{10}$ and trip intensity from January 12 to March 27, 2019 and those for the same period in 2020 are presented in Fig. 3(B), respectively.

As shown in Fig. 3(B), between January 12 and March 27, 2019, in Shenzhen, Guangzhou, and Foshan, the $\mathrm{PM}_{10}$ concentrations ranged between 18.0 and 119 , between 15.0 and 124 , and between 19.0 and $149 \mu \mathrm{g} \mathrm{m}^{-3}$ and averaged $40.9,55.2$, and $62.3 \mu \mathrm{g} \mathrm{m} \mathrm{m}^{-3}$, respectively. While those during 2020 ranged from 9.00-65.0, 6.00-75.0, and 6.00$87.0 \mu \mathrm{g} \mathrm{m}^{-3}$ and averaged 35.2, 38.5, and $39.6 \mu \mathrm{g} \mathrm{m}^{-3}$, respectively, which was $13.9 \%, 30.2 \%$, and $36.5 \%$ lower than that from January 12 to March 27, 2019. Based on the data from the three cities, from January 12 to March 26
2020, the average $\mathrm{PM}_{10}$ concentration decreased by $28.5 \%$ compared with that during the same period in 2019. When the trip intensity of Shenzhen, Guangzhou, and Foshan was less than 4.3, 4.2, and 3.2, respectively, the $\mathrm{PM}_{10}$ concentrations corresponding to the same trip intensity were higher in 2020 than in 2019. Sources of coarse particulate $\left(\mathrm{PM}_{10}\right)$ matter mainly includes nature and human activities, such as sand and dust storms, natural dust and industrial production activities (Querol et al., 2004; Xu et al., 2017). When the concentration of particulate matter discharged by a motor vehicle is reduced due to reduction in trip intensity, movement of polluted air generated by heating from northern China to southern regions can significantly affect the local $\mathrm{PM}_{10}$ levels in the three cities.

It's clear that $\mathrm{PM}_{10}$ concentrations in the three cities from January 12 to March 26 in 2020 were greatly reduced, indicating that the reduction in particulate mass emissions was caused by factory shutdowns and people staying home during the Chinese New Year holiday and the epidemic control period.

\section{$\mathrm{SO}_{2}$ Concentration}

Sulfur dioxide $\left(\mathrm{SO}_{2}\right)$ is a colorless, reactive gas produced when burning sulfur-containing fuels such as coal and petroleum (Kyrkilis et al., 2007; Khattak et al., 2013). The daily concentration of $\mathrm{SO}_{2}$ and trip intensity from January 12 to March 272019 and those in the same period in 2020 are presented in Fig. 3(C), respectively.

As shown in Fig. 3(C), between January 12 and March 27, 2019, in Shenzhen, Guangzhou and Foshan, the $\mathrm{SO}_{2}$ concentrations were between 1.05 and $2.80 \mathrm{ppb}, 1.40$ and $3.50 \mathrm{ppb}$, and 1.05 and $5.60 \mathrm{ppb}$ and averaged 1.71, 2.11, and $2.96 \mathrm{ppb}$, respectively. Those in 2020 ranged from $1.75-2.45 \mathrm{ppb}, 1.40-3.15 \mathrm{ppb}$, and $1.40-3.50 \mathrm{ppb}$, and averaged 1.82, 2.02, and $2.14 \mathrm{ppb}$. The average value of $\mathrm{SO}_{2}$ in Guangzhou and Foshan in 2020 decreased by $4.2 \%$ and $27.6 \%$ compared with that during the same period in 2019 , while Shenzhen increased by $6.3 \%$. Based on the combined data from the three cities, from January 12 to March 26 2020 , the average $\mathrm{SO}_{2}$ decreased by $11.8 \%$ compared with that during the same period in 2019. When the trip intensity of Shenzhen, Guangzhou and Foshan were less than 4.4, 4.5, and 2.6, respectively, the $\mathrm{SO}_{2}$ concentrations corresponding to the same trip intensity were higher in 2020 than in 2019. Sources of sulfur dioxide $\left(\mathrm{SO}_{2}\right)$ mainly include human activities and natural processes, such as the burning of biofuels, motor vehicle emissions, animal catabolism, natural sulfur cycles, and volcanic eruption (Kettle and Andreae, 2000; Halmer et al., 2002; Dentener et al., 2006). When the concentration of $\mathrm{SO}_{2}$ emitted by the fossil fuel combustion was reduced due to the reduction in trip intensity, the movement of air in northern China with excessive sulfur dioxide $\left(\mathrm{SO}_{2}\right)$ concentration to the three cities can affect the local sulfur dioxide level.

Human activities are the main cause of overproduction and emission of sulfur dioxide, including fossil fuel combustion, manufacturing of chemical products, and the burning of biomass (Kettle and Andreae, 2000; Halmer et al., 2002; Dentener et al., 2006; Lee et al., 2008) and China is the 



Fig. 3(B). The trip intensity and daily concentration of $\mathrm{PM}_{10}$ from January 12 to March 27, 2019 and those in 2020 during the same period in Shenzhen, Guangzhou, and Foshan, respectively.

world's largest coal producer and consumer (Kurokawa et al., 2013; Kato et al., 2016). It can be seen that $\mathrm{SO}_{2}$ concentrations in Guangzhou and Foshan from January 12 to March 26 in 2020 were reduced, indicating that factory shutdowns caused by the Chinese New Year holiday and epidemic prevention actions led to significant reductions in $\mathrm{SO}_{2}$ emissions. $\mathrm{SO}_{2}$ concentrations in Shenzhen from January 12 to March 26 in 2020 increased, which may have been a result of the polluted northern air brought by the monsoon.

\section{CO Concentration}

Carbon monoxide $(\mathrm{CO})$ is a colorless, odorless gas that forms when the carbon in fuels does not completely burn. About $60 \%$ of CO emissions nationwide come from vehicle exhaust, and up to $95 \%$ is found in cities. Other sources include fuel combustion in industrial processes and natural sources such as wildfires (Kyrkilis et al., 2007). The daily concentration of $\mathrm{CO}$ and trip intensity in January 12 to March 27, 2019 and those over the same period in 2020 are presented in Fig. 3(D), respectively. 

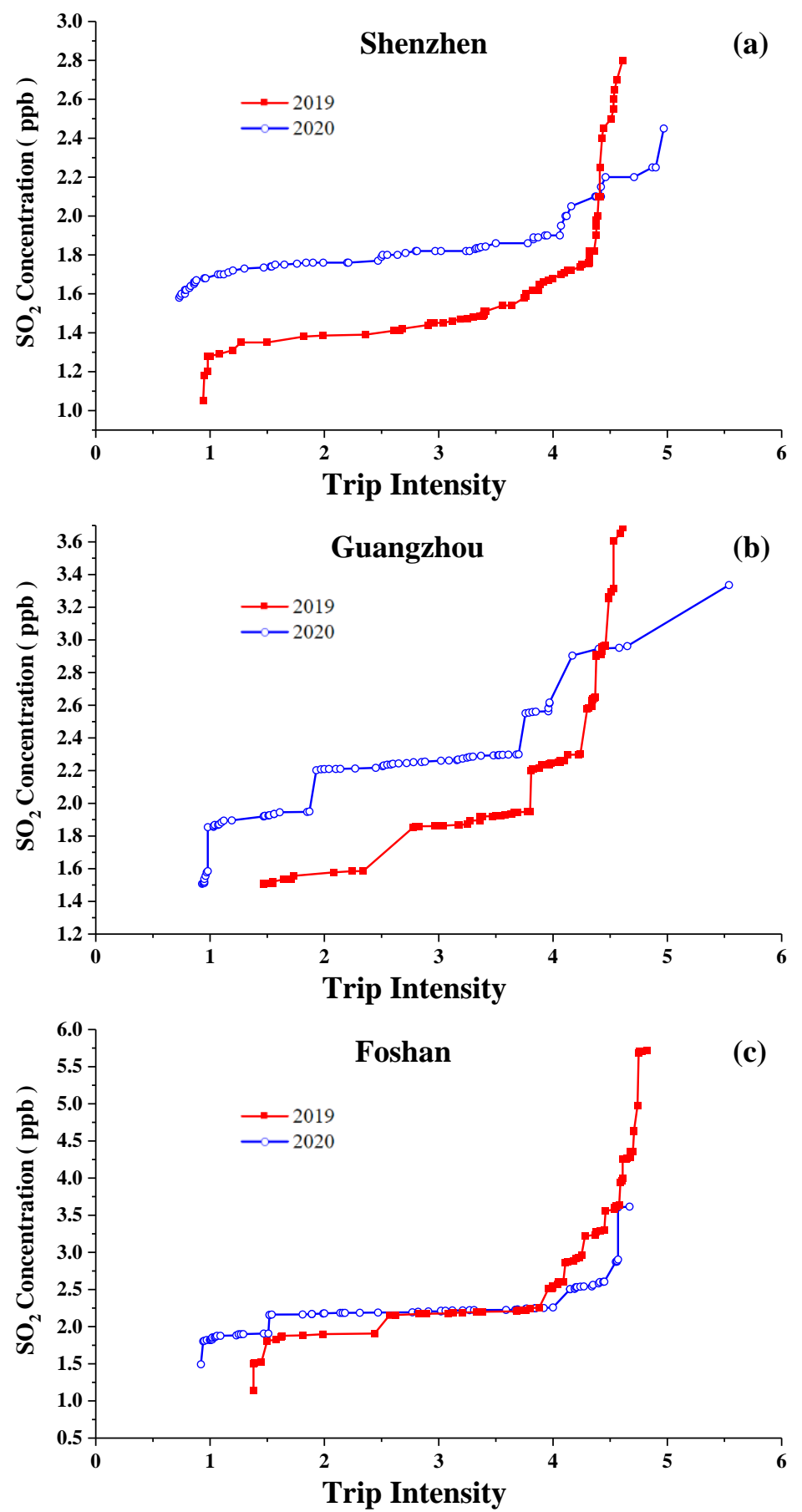

Fig. 3(C). The trip intensity and daily concentration of $\mathrm{SO}_{2}$ from January 12 to March 272019 and those during the sample period in 2020 in Shenzhen, Guangzhou, and Foshan, respectively.

As shown in Fig. 3(D), between January 12 and March 27, 2019, in Shenzhen, Guangzhou and Foshan, the CO concentrations ranged from $0.40-0.96,0.48-1.28$, and $0.48-1.20 \mathrm{ppm}$, and averaged $0.58,0.80$, and $0.81 \mathrm{ppm}$, respectively. While those during 2020 ranged from 0.40 $0.80,0.48-0.96$, and $0.40-0.96 \mathrm{ppm}$, and averaged 0.49 , 0.62 , and $0.57 \mathrm{ppm}$, respectively. The average values of CO in Shenzhen, Guangzhou, and Foshan in 2020 decreased by $15.6 \%, 21.8 \%$, and $29.3 \%$ compared with those during the same period in 2019. Based on the combined data from the three cities, from January 12 to March 26 2020, the average CO decreased by $22.9 \%$ compared with that during the same period in 2019. When the trip intensity of Shenzhen and Guangzhou were less than 4.0 and 4.3, the CO concentrations corresponding to the same trip intensity were higher in 2020 than in 2019. Carbon monoxide (CO) in the atmosphere is mainly derived from the incomplete combustion of fossil fuels and biofuels. These combustion processes also emit nitrogen oxides and volatile organic compounds (Wang et al., 2018). During the epidemic control period, the CO 

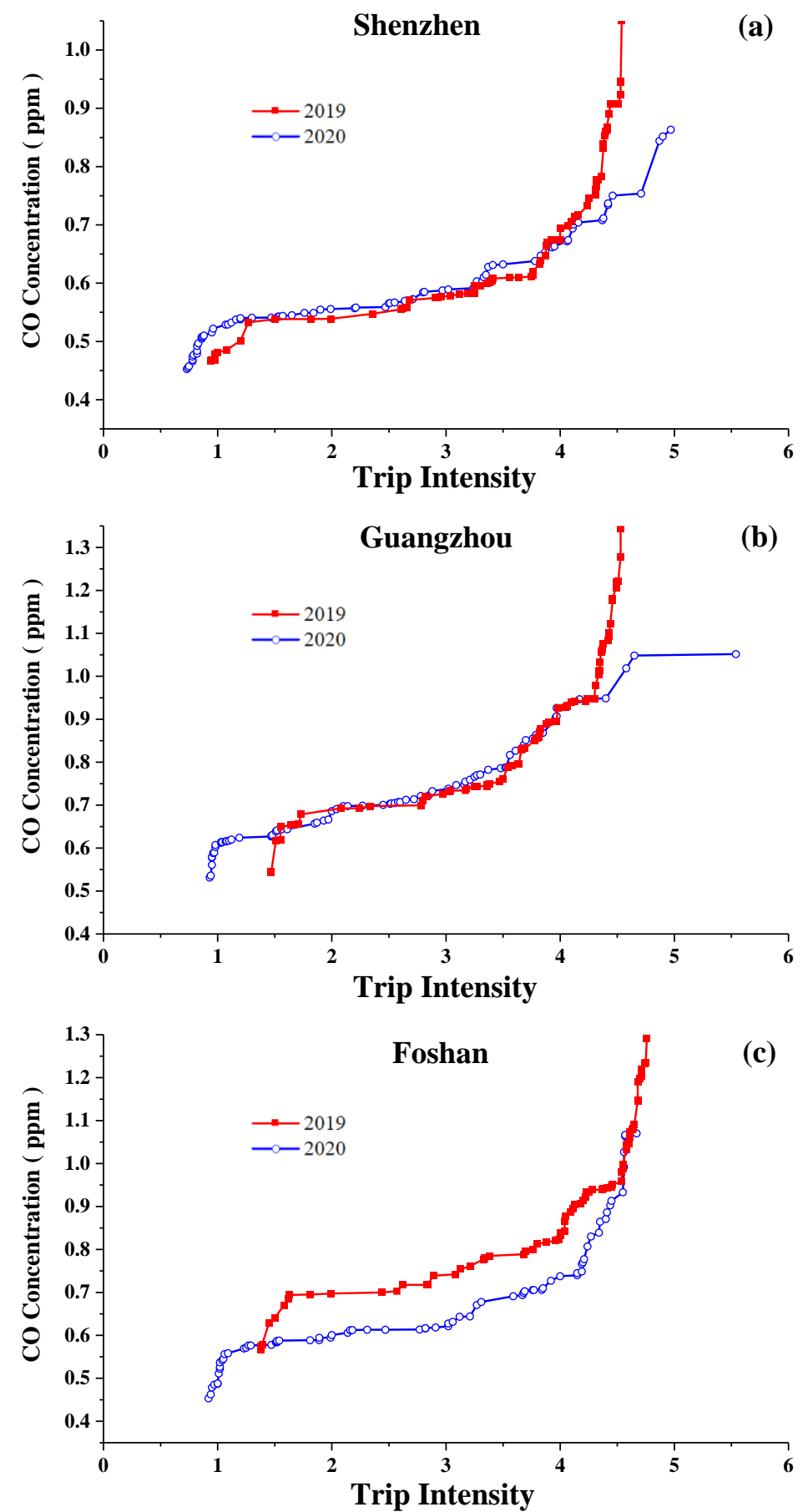

Fig. 3(D). The trip intensity and daily concentration of CO from January 12 to March 272019 and those of 2020 over the same period in Shenzhen, Guangzhou, and Foshan, respectively.

emitted by civil boilers and power stations was significantly affected. Therefore, the same travel intensity corresponded to higher $\mathrm{CO}$ concentrations in 2020. In Foshan, the CO concentrations corresponding to the same trip intensity were higher in 2019 than in 2020. Foshan is an industrial city, and most factories did not return to normal production capacity during the epidemic control period, which means that the amount of $\mathrm{CO}$ derived from industrial production was significantly reduced.

It can be seen that $\mathrm{CO}$ concentrations in the three cities from January 12 to March 26, 2020 were obviously reduced, indicating that the strict isolation measures had a significant impact on the generation and transformation of $\mathrm{CO}$.

\section{$\mathrm{NO}_{2}$ Concentration}

Nitrogen dioxide $\left(\mathrm{NO}_{2}\right)$ mainly comes from social production activities such as chemical plants and motor vehicles (Cheng et al., 2018). $\mathrm{NO}_{2}$ levels are often low and pose little immediate threat to human health. However, $\mathrm{NO}_{2}$ is a cause for concern because it plays an important role in 
the formation of ozone, particle pollution, smog and acid rain (Kyrkilis et al., 2007). The daily concentration of $\mathrm{NO}_{2}$ and trip intensity in January 12 to March 27, 2019 and those during the same period in 2020 are presented in Fig. 3(E), respectively.

As shown in Fig. 3(E), between January 12 and March 27, 2019, in Shenzhen, Guangzhou, and Foshan, the $\mathrm{NO}_{2}$ concentrations were between 4.90 and $35.5 \mathrm{ppb}, 7.80$ and $52.1 \mathrm{ppb}, 4.90$ and $44.8 \mathrm{ppb}$, and averaged 12.2, 23.6, and $21.6 \mathrm{ppb}$, respectively. Those during 2020 ranged from
4.90-19.5, 4.90-31.7, and 4.90-32.1 ppb, and averaged of $9.80,16.5$, and $14.5 \mathrm{ppb}$, respectively. These values were, $20.2 \%, 30.1 \%$, and $33 \%$ lower than those of during January 12 to March 27, 2019. Based on the data from the three cities, from January 12 to March 26 2020, the average $\mathrm{NO}_{2}$ decreased by $29.1 \%$ compared with that during the same period in 2019. When the trip intensity of Shenzhen, Guangzhou, and Foshan was less than 3.7, 4.0, and 1.6, respectively, the $\mathrm{O}_{3}$ concentrations corresponding to the same trip intensity were higher in 2020 than in 2019. Nitrogen dioxide $\left(\mathrm{NO}_{2}\right)$ mainly
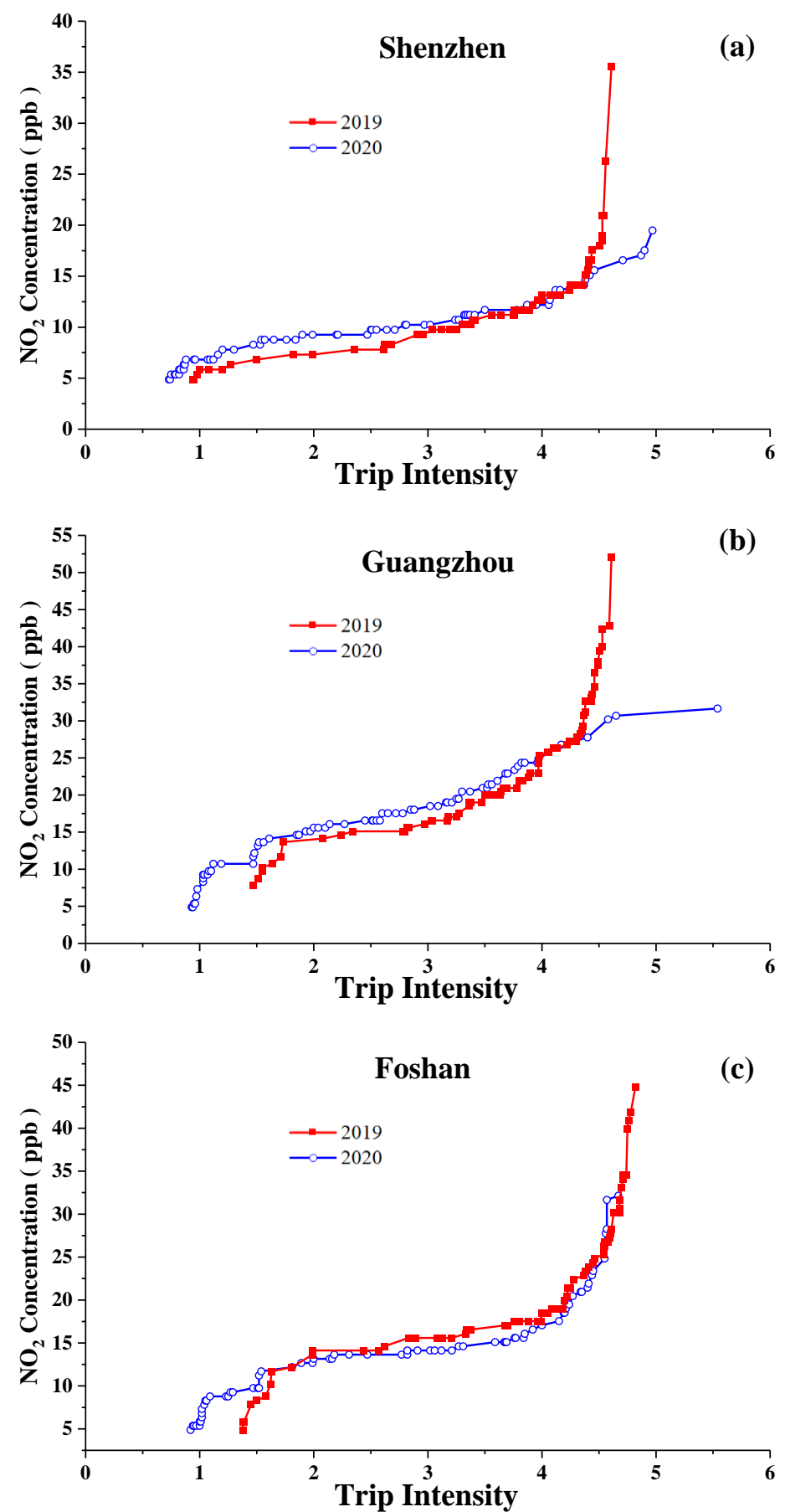

Fig. 3(E). The trip intensity and daily concentrations of $\mathrm{NO}_{2}$ from January 12 to March 272019 and those of 2020 during the same period in Shenzhen, Guangzhou and Foshan respectively. 
comes from social production activities such as chemical plants and motor vehicles (Cheng et al., 2018). When the concentration of $\mathrm{NO}_{2}$ from the automobile exhaust was reduced due to the reduction in trip intensity, the $\mathrm{NO}_{2}$ sources from the combustion of fossil fuels, such as power plants continued normal operations and produced atmospheric pollutants.

$\mathrm{NO}_{\mathrm{x}}$ from vehicle emissions has a significant impact on the concentration of $\mathrm{NO}_{2}$ in the urban atmospheric environment (Cheng et al., 2018). It can be seen that $\mathrm{NO}_{2}$ concentrations in the three cities from January 12 to March 26, 2020 were obviously reduced, indicating that a series of measures for epidemic prevention reduced $\mathrm{NO}_{2}$ industrial and traffic emissions.

\section{$\mathrm{O}_{3}$ Concentration}

Ozone is a gas composed of three atoms of oxygen. Ozone occurs both in the Earth's upper atmosphere and at the ground level (Kyrkilis et al., 2007). $\mathrm{O}_{3}$ is generated by photochemical reactions and can increase susceptibility to respiratory infections ( $\mathrm{Wu}$ et al., 2015). Nitrogen dioxide $\left(\mathrm{NO}_{2}\right)$ as the precursor of ozone, and it participates in the formation of generate nitrate $\left(\mathrm{NO}_{3}{ }^{-}\right)$(Bowman et al., 1994). The daily concentrations of $\mathrm{O}_{3}$ and trip intensity from January 12 to March 27, 2019 and those during the same period in 2020 are presented in Fig. 3(F), respectively.

As shown in Fig. 3(F), between January 12 and March 27, 2019, in Shenzhen, Guangzhou, and Foshan, the $\mathrm{O}_{3}$ concentrations ranged from 14.5-60.2, 5.10-75.1, and 3.70$73.3 \mathrm{ppb}$, and averaged $36.2,32.0$, and $29.1 \mathrm{ppb}$, respectively. Those in 2020 during the same period ranged from 21.5$60.2,13.1-70.0$, and 9.80-67.7 ppb, and averaged 36.1, 35.6 , and $33.7 \mathrm{ppb}$, respectively. The average values of $\mathrm{O}_{3}$ in Guangzhou and Foshan from January 12 to March 26, 2020 increased by $11.4 \%$ and $15.8 \%$, respectively, compared to those in 2019, while Shenzhen remained unchanged. Based on the combined data from the three cities, from January 12 to March 26, 2020, the average $\mathrm{O}_{3}$ increased by $8.41 \%$ compared with that during the same period in 2019. However, the $\mathrm{O}_{3}$ concentrations corresponding to the same trip intensity were higher in 2020 than in 2019, which was due to the low concentration of nitrogen dioxide making the generated ozone cannot be effectively converted (Zhao et al., 2018).

Ozone is a secondary pollutant controlled by meteorological conditions and precursor pollutants. The precursors are generally $\mathrm{NO}_{\mathrm{x}}$, VOCs, CO, and $\mathrm{CH}_{4}$ (Vingarzan 2004; Kleinman, 2005). Because there are large number of anthropogenic sources in urban and industrial areas, the concentrations of $\mathrm{NO}_{\mathrm{x}}$ and VOCs are high, and they are important precursors for controlling ozone concentration (Lal et al., 2000). It is well known that the reciprocal transformation of $\mathrm{O}_{3}, \mathrm{NO}$ and $\mathrm{NO}_{2}$ in atmospheric conditions is generally dominated by the following reactions (Clapp et al., 2001):

$$
\begin{aligned}
& \mathrm{NO}+\mathrm{O}_{3} \rightarrow \mathrm{NO}_{2}+\mathrm{O}_{2} \\
& \mathrm{NO}_{2}+\mathrm{h} v\left(+\mathrm{O}_{2}\right) \rightarrow \mathrm{NO}+\mathrm{O}_{3}
\end{aligned}
$$

Although there were many precursors of $\mathrm{O}_{3}$ in the atmosphere in 2019, the meteorological conditions were not conducive to $\mathrm{O}_{3}$ generation, and the concentration of $\mathrm{O}_{3}$ in the atmosphere was at low levels in 2019, so the concentration of $\mathrm{O}_{3}$ in 2019 was lower than that in 2020 .

\section{Distribution of the Six AQI Classes}

In order to study the distribution of AQI, this study carried out statistical analysis and comparison between January 12 and March 27, 2019 and those in 2020 during the same period, respectively. The distribution of the six AQI Classes in Shenzhen, Guangzhou, and Foshan were shown and compared in Fig. 4.

In Shenzhen, from January 12 to March 27, 2019, the daily AQI ranged between 21 and 99 and averaged 45.9, while in 2020, it ranged between 19 and 74 and averaged 42.2, which was $8.2 \%$ lower than that in 2019. Fig. 4 shows that the proportions of classes I, II, III, IV, V, and VI were $72.4 \%, 27.6 \%, 0 \%, 0 \%, 0 \%$, and $0 \%$ from January 12 to March 27, 2019. During the same period in 2020, the proportions of classes I, II, III, IV, V, and VI were $84.2 \%$, $15.8 \%, 0 \%, 0 \%, 0 \%$, and $0 \%$, respectively. The proportions of Class I showed an obvious increase from $72.4 \%$ to $84.2 \%$, while the proportions of Class II decreased from $27.6 \%$ to $15.8 \%$, from January 12 to March 26, 2020. This was due to the reduction of industrial production activities resulting in the air pollutant generation and emissions during the epidemic control period.

In Guangzhou, from January 12 to March 27, 2019, the daily AQI ranged between 25 and 121 and averaged 63.2, while in 2020, it ranged between 20 and 92 and averaged 51.8, which was $18.1 \%$ lower than that in 2019. Fig. 4 shows that the proportions of classes I, II, III, IV, V and VI were $30.3 \%, 61.9 \%, 7.8 \%, 0 \%, 0 \%$, and $0 \%$, respectively. During the same period of 2020, the proportions of classes I, II, III, IV, V, and VI were $48.7 \%, 51.3 \%, 0 \%, 0 \%, 0 \%$, and $0 \%$. The combined proportions of classes I and II increased from $92.2 \%$ to $100 \%$, while Class III decreased from $7.8 \%$ to $0 \%$. Compared with the non-epidemic period, the air quality in Guangzhou improved significantly from January 12 to March 26,2020 , which was due to the reduction of production activities caused by a series of strict control measures.

In Foshan, from January 12 to March 27, 2019, the daily AQI ranged between 23 and 108 and averaged 60.1, while the daily AQI in 2020 ranged between 18 and 87 and averaged 48.1, which was $19.9 \%$ lower than that in 2019. Fig. 4 shows that the proportions of classes I, II, III, IV, V, and VI were $32.9 \%, 61.8 \%, 5.3 \%, 0 \%, 0 \%$, and $0 \%$, respectively. During the same period of 2020, the proportions of classes I, II, III, IV, V and VI were $55.3 \%, 44.7 \%, 0 \%, 0 \%, 0 \%$, and $0 \%$. The combined proportions of classes I and II increased from $94.7 \%$ to $100 \%$, while class III decreased from $5.3 \%$ to $0 \%$. This was because strict COVID-19 epidemic prevention and control actions were taken in Guangdong Province, which means that the air pollutants generated from industrial sources and automobile emissions were greatly reduced.

From January 12 to March 27, in Shenzhen, the daily AQI averaged 45.9 in 2019 and 42.2 in 2020. In Guangzhou, the daily AQI averaged 63.2 in 2019 and 51.8 in 2020. In 

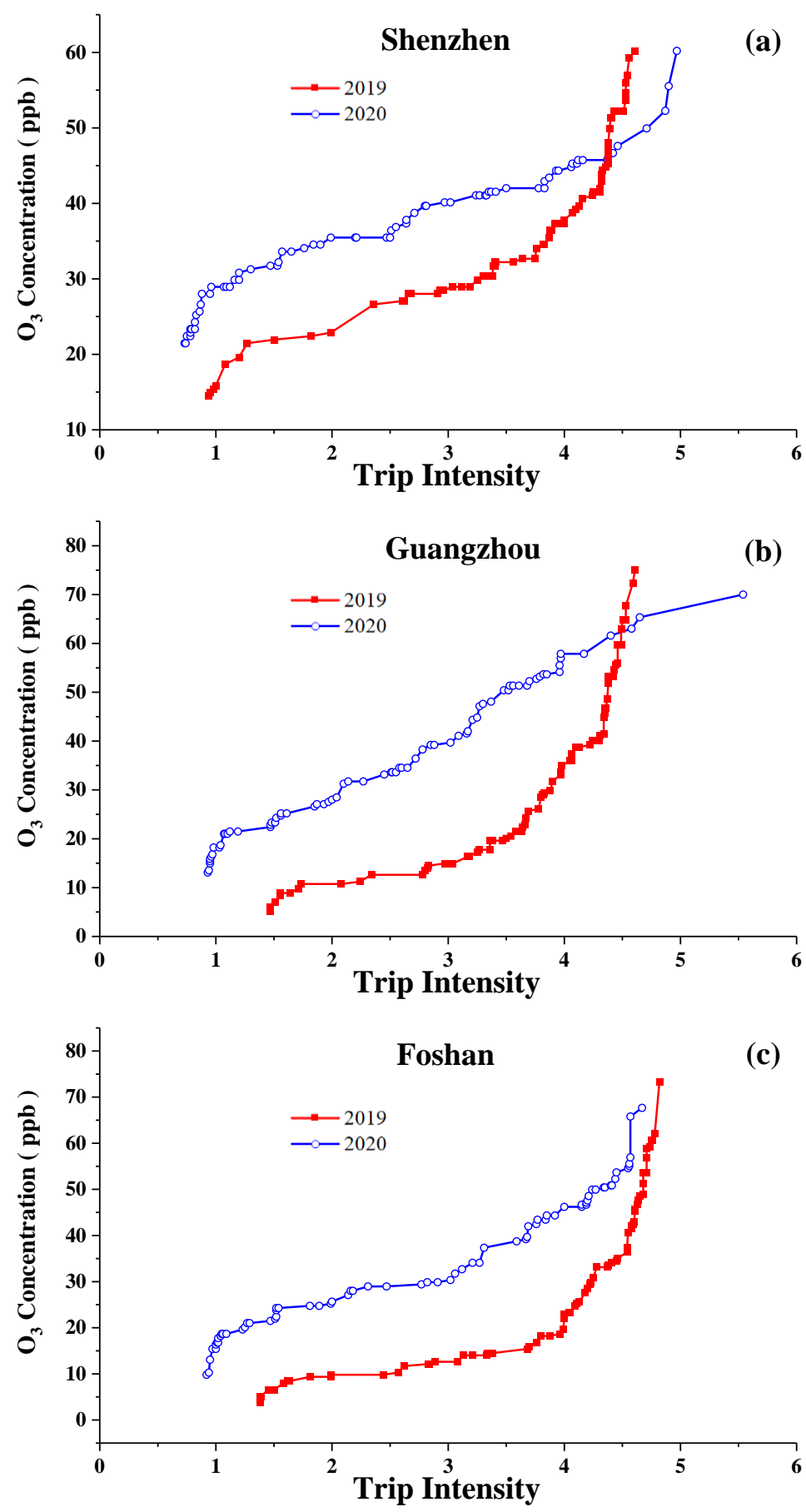

Fig. 3(F). The trip intensity and daily concentrations of $\mathrm{O}_{3}$ from January 12 to March 27, 2019 and those in 2020 during the same period in Shenzhen, Guangzhou and Foshan respectively.

Foshan, the daily AQI averaged 60.1 in 2019 and 48.1 in 2020. The AQI level rankings of the three cities were as follows: Guangzhou > Foshan > Shenzhen, which showed that Shenzhen had the best air quality, while Guangzhou had the worst. Fig. 4 shows the distribution of the AQI classes for the three cities combination between January 12 and March 272019 and those in 2020. In the three cities, January 12 to March 27, 2019, the proportions of classes I, II, III, IV, V, and VI were $45.2 \%, 50.4 \%, 4.4 \%, 0 \%, 0 \%$, and $0 \%$, respectively. During the same period of 2020 , the proportions of classes I, II, III, IV, V, and VI were $62.7 \%$, $37.3 \%, 0 \%, 0 \%, 0 \%$, and $0 \%$. Compared to the same period in 2019, the proportions of class I showed an obvious increase (from $45.2 \%$ to $62.7 \%$ ), while the proportions of class III decreased from $4.4 \%$ to $0 \%$, between January 12 and March 26,2020 . This indicated that compared with the same period in 2019, the air quality in Shenzhen, Guangzhou, and Foshan between January 12 and March 26, 2020 improved very significantly. There may be two reasons for a decrease in the AQI in 2020. The first reason is that January 24, 2020 

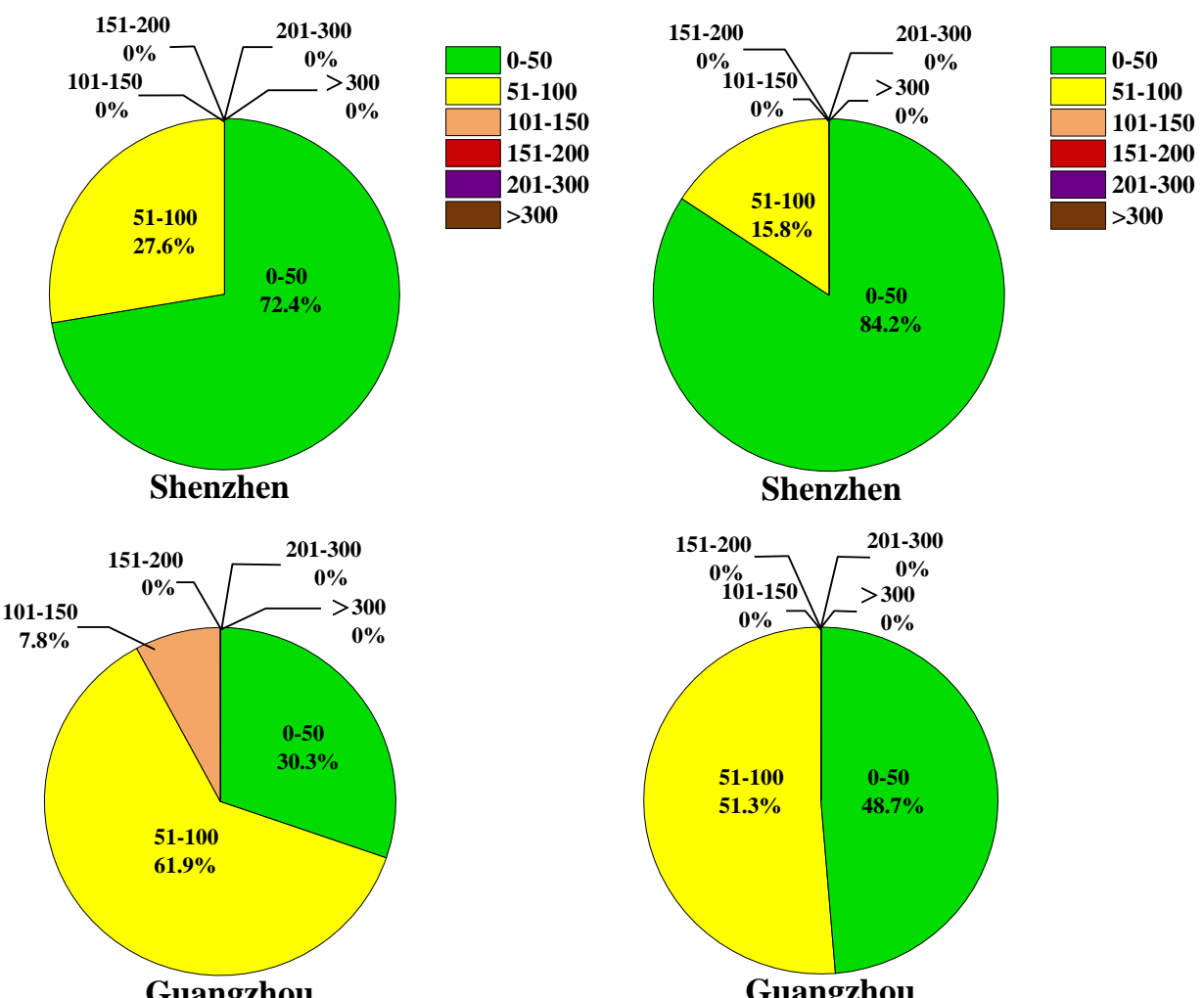

Guangzhou

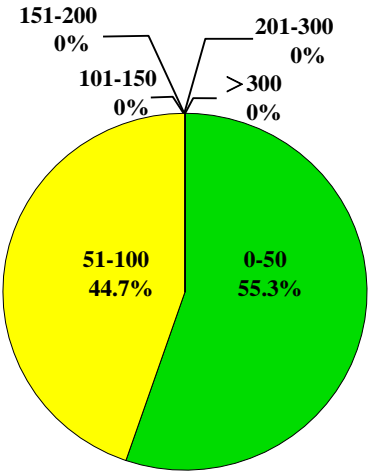

Foshan

January 12 to March 28, 2019

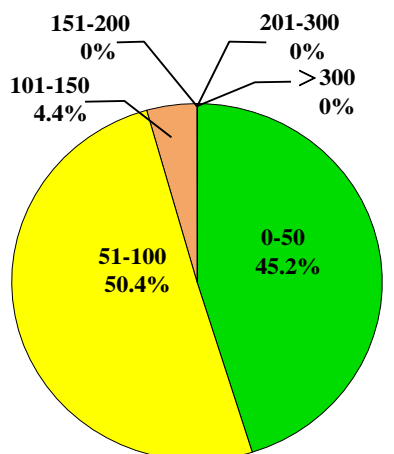

Three Cities



January 12 to March 28, 2019

January 12 to March 27, 2020

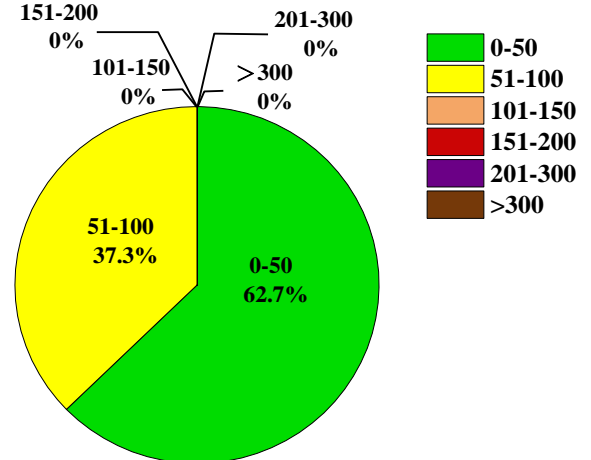

Three Cities

January 12 to March 27, 2020

Fig. 4. The distribution of the six AQI categories for Shenzhen, Guangzhou, and Foshan from January 12 to March 27,2019 and those in 2020 during the same period. 
was the traditional Chinese New Year, so a large number of factories were closed for the holiday, which greatly reduced the industrial emission sources of air pollutants. Second, during the epidemic control period, local residents cancel unnecessary travel activities, which led to a substantial reduction in non-essential production activities and a marked decrease in travel frequency.

\section{Five Top Daily AQI Values and Indicator Air Pollutants}

The five highest daily AQI values from January 12 to March 27, 2017-2020 and related air pollutants in Shenzhen, Guangzhou, and Foshan are shown in Tables 1, 2 and 3, respectively.

As shown in Table 1, in Shenzhen, the top five days with the highest AQIs from January 12 to March 27, 2017 were February 13, March 3, January 12, February 12 and February 10, 2017, with AQIs of 89, 87, 85, 83 and 80, respectively. On February 13, 2017, the concentrations of $\mathrm{PM}_{2.5}, \mathrm{PM}_{10}, \mathrm{SO}_{2}, \mathrm{CO}, \mathrm{NO}_{2}$, and $\mathrm{O}_{3}$ were $51.0 \mu \mathrm{g} \mathrm{m}^{-3}$, $58.0 \mu \mathrm{g} \mathrm{m}^{-3}, 3.15 \mathrm{ppb}, 0.72 \mathrm{ppm}, 17.0 \mathrm{ppb}$ and $68.6 \mathrm{ppb}$, respectively, and on February 10, they were $60.0 \mu \mathrm{g} \mathrm{m}^{-3}$, $69.0 \mu \mathrm{g} \mathrm{m}^{-3}, 3.85 \mathrm{ppb}, 0.80 \mathrm{ppm}, 9.25 \mathrm{ppb}$, and $47.1 \mathrm{ppb}$ respectively, for which the indicator air pollutants on these five days were $\mathrm{O}_{3}, \mathrm{O}_{3}, \mathrm{PM}_{2.5}, \mathrm{O}_{3}$, and $\mathrm{PM}_{2.5}$, respectively. The top five days with the highest AQIs from January 12 to March 27, 2018 were January 22, January 17, January 16, January 23, and January 18, with AQIs of 125, 113, 88, 83 and 79, respectively. On January 22, 2018, the concentrations of $\mathrm{PM}_{2.5}, \mathrm{PM}_{10}, \mathrm{SO}_{2}, \mathrm{CO}, \mathrm{NO}_{2}$, and $\mathrm{O}_{3}$ were $95.0 \mu \mathrm{g} \mathrm{m}^{-3}$, $134 \mu \mathrm{g} \mathrm{m}^{-3}, 3.85 \mathrm{ppb}, 0.80 \mathrm{ppm}, 30.7 \mathrm{ppb}$ and $62.1 \mathrm{ppb}$, respectively; on January 18 , they were $58.0 \mu \mathrm{g} \mathrm{m}^{-3}$, $87.0 \mu \mathrm{g} \mathrm{m}^{-3}, 3.15 \mathrm{ppb}, 0.64 \mathrm{ppm}, 25.3 \mathrm{ppb}$, and $55.1 \mathrm{ppb}$ respectively, and the indicator air pollutants for these five days were $\mathrm{PM}_{2.5}, \mathrm{PM}_{2.5}, \mathrm{NO}_{2}, \mathrm{PM}_{2.5}$ and $\mathrm{PM}_{2.5}$, respectively.
In Shenzhen, January 12, January 22, March 17, January 24, and January 23 were the top five days with the highest AQIs from January 12 to March 27, 2019 were 99, 84, 75, 73 and 72, respectively. On January 12, 2019, the concentrations of $\mathrm{PM}_{2.5}, \mathrm{PM}_{10}, \mathrm{SO}_{2}, \mathrm{CO}, \mathrm{NO}_{2}$, and $\mathrm{O}_{3}$ were $74.0 \mu \mathrm{g} \mathrm{m}^{-3}$, $119 \mu \mathrm{g} \mathrm{m}^{-3}, 2.80 \mathrm{ppb}, 0.96 \mathrm{ppm}, 35.6 \mathrm{ppb}$ and $31.7 \mathrm{ppb}$, respectively, and on January 23 , they were $52.0 \mu \mathrm{g} \mathrm{m}^{-3}$, $81.0 \mu \mathrm{g} \mathrm{m}^{-3} 2.80 \mathrm{ppb}, 0.80 \mathrm{ppm}, 19.0 \mathrm{ppb}$, and $52.3 \mathrm{ppb}$, respectively, and the indicator air pollutants for these five days were $\mathrm{PM}_{2.5}, \mathrm{PM}_{2.5}, \mathrm{O}_{3}, \mathrm{PM}_{2.5}$, and $\mathrm{PM}_{2.5}$.

The top five days with the highest AQIs from January 12 to March 26, 2020, in Shenzhen, were on February 22, March 16, March 15, January 16, and February 23, with AQIs of 75, 66, 60, 58, and 56, respectively. On February 22, 2020, the concentrations of $\mathrm{PM}_{2.5}, \mathrm{PM}_{10}, \mathrm{SO}_{2}, \mathrm{CO}, \mathrm{NO}_{2}$, and $\mathrm{O}_{3}$ were $28.0 \mu \mathrm{g} \mathrm{m}^{-3}, 43.0 \mu \mathrm{g} \mathrm{m}^{-3}, 2.10 \mathrm{ppb}, 0.48 \mathrm{ppm}$, $12.2 \mathrm{ppb}$ and $60.2 \mathrm{ppb}$, respectively, and on February 23, they were $23.0 \mu \mathrm{g} \mathrm{m}^{-3}, 39.0 \mathrm{\mu g} \mathrm{m}^{-3}, 1.75 \mathrm{ppb}, 0.48 \mathrm{ppm}$, $6.33 \mathrm{ppb}$, and $49.9 \mathrm{ppb}$, respectively, and the indicator air pollutants for these five days were $\mathrm{O}_{3}, \mathrm{O}_{3}, \mathrm{O}_{3}, \mathrm{PM}_{10}$, and $\mathrm{PM}_{10}$.

The above results indicated that in Shenzhen, the average value of the 15 days with the highest AQIs from January 12 to March 27, 2017-2019 (non-epidemic period) was 87.7, and the corresponding average concentrations of $\mathrm{PM}_{2.5}, \mathrm{PM}_{10}$, $\mathrm{SO}_{2}, \mathrm{CO}, \mathrm{NO}_{2}$, and $\mathrm{O}_{3}$ were $59.3 \mu \mathrm{g} \mathrm{m}^{-3}, 87.0 \mu \mathrm{g} \mathrm{m}^{-3}, 3.05$ ppb, $0.76 \mathrm{ppm}, 21.6 \mathrm{ppb}$, and $53.9 \mathrm{ppb}$, respectively. The average AQI of the top five days with the highest AQI from January 12 to March 26, 2020 (epidemic prevention and control period) was approximately 63 , and the corresponding average concentrations of $\mathrm{PM}_{2.5}, \mathrm{PM}_{10}, \mathrm{SO}_{2}, \mathrm{CO}, \mathrm{NO}_{2}$, and $\mathrm{O}_{3}$ were $29.2 \mu \mathrm{g} \mathrm{m}^{-3}, 50.2 \mu \mathrm{g} \mathrm{m}^{-3}, 1.96 \mathrm{ppb}, 0.50 \mathrm{ppm}$, $9.90 \mathrm{ppb}$, and $51.5 \mathrm{ppb}$, which were $50.8 \%$, 42.3\%, 35.9\%, $34.5 \%, 53.9 \%$ and $4.3 \%$, lower than those in 2017-2019,

Table 1. The top five days with the highest AQIs by year in Shenzhen from January 12 to March 27 in 2017, 2018, 2019, and 2020.

\begin{tabular}{|c|c|c|c|c|c|c|c|}
\hline Date & AQI & $\mathrm{PM}_{2.5}\left(\mu \mathrm{g} \mathrm{m}^{-3}\right)$ & $\mathrm{PM}_{10}\left(\mu \mathrm{g} \mathrm{m}^{-3}\right)$ & $\mathrm{SO}_{2}(\mathrm{ppb})$ & $\mathrm{CO}(\mathrm{ppm})$ & $\mathrm{NO}_{2}(\mathrm{ppb})$ & $\mathrm{O}_{3}(\mathrm{ppb})$ \\
\hline Feb. 13, 2017 & 89 & 51.0 & 58.0 & 3.15 & 0.72 & 17.0 & 68.6 \\
\hline Mar. 3, 2017 & 87 & 42.0 & 80.0 & 3.85 & 0.64 & 14.1 & 67.7 \\
\hline Jan. 12, 2017 & 85 & 62.0 & 86.0 & 2.45 & 1.12 & 19.5 & 17.3 \\
\hline Feb. 12, 2017 & 83 & 56.0 & 74.0 & 3.85 & 0.72 & 16.6 & 65.3 \\
\hline Feb. 10, 2017 & 80 & 60.0 & 69.0 & 3.85 & 0.80 & 9.3 & 47.1 \\
\hline Jan. 22, 2018 & 125 & 95.0 & 134 & 3.85 & 0.80 & 30.7 & 62.1 \\
\hline Jan. 17, 2018 & 113 & 85.0 & 120 & 4.20 & 0.80 & 42.4 & 70.0 \\
\hline Jan. 16, 2018 & 88 & 50.0 & 83.0 & 2.80 & 0.64 & 34.1 & 58.8 \\
\hline Jan. 23, 2018 & 83 & 61.0 & 90.0 & 2.45 & 0.80 & 18.5 & 44.8 \\
\hline Jan. 18, 2018 & 79 & 58.0 & 87.0 & 3.15 & 0.64 & 25.3 & 55.1 \\
\hline Jan. 12, 2019 & 99 & 74.0 & 119 & 2.80 & 0.96 & 35.6 & 31.7 \\
\hline Jan. 22, 2019 & 84 & 62.0 & 87.0 & 2.45 & 0.80 & 13.2 & 52.3 \\
\hline Mar. 17, 2019 & 75 & 29.0 & 56.0 & 1.75 & 0.40 & 9.7 & 60.2 \\
\hline Jan. 24, 2019 & 73 & 53.0 & 81.0 & 2.45 & 0.72 & 18.5 & 54.6 \\
\hline Jan. 23, 2019 & 72 & 52.0 & 81.0 & 2.80 & 0.80 & 19.0 & 52.3 \\
\hline Feb. 22, 2020 & 75 & 28.0 & 43.0 & 2.10 & 0.48 & 12.2 & 60.2 \\
\hline Mar. 16, 2020 & 66 & 23.0 & 51.0 & 2.10 & 0.40 & 9.3 & 55.5 \\
\hline Mar. 15, 2020 & 60 & 32.0 & 53.0 & 2.10 & 0.56 & 8.8 & 52.3 \\
\hline Jan. 16, 2020 & 58 & 40.0 & 65.0 & 1.75 & 0.56 & 13.2 & 39.7 \\
\hline Feb. 23,2020 & 56 & 23.0 & 39.0 & 1.75 & 0.48 & 6.3 & 49.9 \\
\hline
\end{tabular}


respectively. In Table 1, the average AQI in 2020 was 63, and which was $28.1 \%$ lower than that of 2017-2019 (AQI = 87.7). Compared with the same period in 2017-2019, the air quality from January 12 to March 26, 2020 improved significantly.

As shown in Table 2, in Guangzhou, the top five days with the highest AQIs from January 12 to March 27, 2017 were on February 18, February 17, January 28, February 14, and March 3, with AQIs of 122, 115, 114, 111, and 109, respectively. On February 18, 2017, the concentrations of $\mathrm{PM}_{2.5}, \mathrm{PM}_{10}, \mathrm{SO}_{2}, \mathrm{CO}, \mathrm{NO}_{2}$, and $\mathrm{O}_{3}$ were $72.0 \mu \mathrm{g} \mathrm{m}^{-3}$, $116 \mu \mathrm{g} \mathrm{m}^{-3}, 6.65 \mathrm{ppb}, 0.96 \mathrm{ppm}, 56.5 \mathrm{ppb}$ and $86.3 \mathrm{ppb}$, respectively, and on March 3, they were $60.0 \mu \mathrm{g} \mathrm{m}^{-3}$, $116 \mu \mathrm{g} \mathrm{m}^{-3}, 8.05 \mathrm{ppb}, 0.72 \mathrm{ppm}, 44.8 \mathrm{ppb}$, and $79.3 \mathrm{ppb}$ respectively, and the indicator air pollutants for these five days were $\mathrm{O}_{3}, \mathrm{NO}_{2}, \mathrm{PM}_{2.5}, \mathrm{O}_{3}$, and $\mathrm{O}_{3}$, respectively.

The top five days with the highest AQIs from January 12 to March 27, 2018 were on January 18, February 16, January 20, January 19, and January 17, with AQIs of 183, 180, 160, 149, and 144, respectively. On January 18, 2018, the concentrations of $\mathrm{PM}_{2.5}, \mathrm{PM}_{10}, \mathrm{SO}_{2}, \mathrm{CO}, \mathrm{NO}_{2}$, and $\mathrm{O}_{3}$ were $138 \mu \mathrm{g} \mathrm{m}^{-3}, 169 \mathrm{\mu g} \mathrm{m}^{-3}, 5.95 \mathrm{ppb}, 1.44 \mathrm{ppm}, 79.4 \mathrm{ppb}$, and $50.4 \mathrm{ppb}$, respectively, and on January 17, they were $110 \mu \mathrm{g} \mathrm{m}^{-3}, 146 \mu \mathrm{g} \mathrm{m}^{-3}, 7.00 \mathrm{ppb}, 1.28 \mathrm{ppm}, 63.8 \mathrm{ppb}$, and $55.5 \mathrm{ppb}$, respectively, and the indicator air pollutants on these five days were all $\mathrm{PM}_{2.5}$.

In Guangzhou, the top five days with the highest AQIs from January 12 to March 27, 2019, were on January 25, January 19, January 24, March 12, and March 18, with AQIs of 122, 104, 104, 101, and 101, respectively. On January 25 , 2019, the concentrations of $\mathrm{PM}_{2.5}, \mathrm{PM}_{10}, \mathrm{SO}_{2}, \mathrm{CO}, \mathrm{NO}_{2}$, and $\mathrm{O}_{3}$ were $92.0 \mu \mathrm{g} \mathrm{m}^{-3}, 124 \mu \mathrm{g} \mathrm{m}^{-3}, 2.80 \mathrm{ppb}, 0.96 \mathrm{ppm}$, $52.1 \mathrm{ppb}$, and $63.0 \mathrm{ppb}$, respectively, and on March 18, they were $60.0 \mu \mathrm{g} \mathrm{m}^{-3}, 119 \mu \mathrm{g} \mathrm{m}^{-3}, 3.15 \mathrm{ppb}, 0.88 \mathrm{ppm}, 39.4 \mathrm{ppb}$, and $17.3 \mathrm{ppb}$, respectively, and the indicator air pollutants for these five days were $\mathrm{PM}_{2.5}, \mathrm{NO}_{2}, \mathrm{NO}_{2}, \mathrm{O}_{3}$, and $\mathrm{NO}_{2}$, respectively.

The top five days with the highest AQIs from January 12 to March 26 2020, in Guangzhou, were on February 23, February 22, January 14, February 21, and March 12, with AQIs of 92, 84, 82, 80 and 79, respectively. On February 23, 2020, the concentrations of $\mathrm{PM}_{2.5}, \mathrm{PM}_{10}, \mathrm{SO}_{2}, \mathrm{CO}, \mathrm{NO}_{2}$, and $\mathrm{O}_{3}$ were $37.0 \mu \mathrm{g} \mathrm{m}^{-3}, 55.0 \mu \mathrm{g} \mathrm{m}^{-3}, 2.45 \mathrm{ppb}, 0.64 \mathrm{ppm}$, $19.5 \mathrm{ppb}$, and $70.0 \mathrm{ppb}$, respectively, and on March 12, they were $34.0 \mu \mathrm{g} \mathrm{m}^{-3}, 68.0 \mu \mathrm{g} \mathrm{m}^{-3}, 2.80 \mathrm{ppb}, 0.72 \mathrm{ppm}$, $30.7 \mathrm{ppb}$, and $18.7 \mathrm{ppb}$, respectively, and the indicator air pollutants for these five days were $\mathrm{O}_{3}, \mathrm{O}_{3}, \mathrm{NO}_{2}, \mathrm{O}_{3}$, and $\mathrm{NO}_{2}$, respectively.

The above results indicated that in Guangzhou, the average value of the 15 days with the highest AQI from January 12 to March 27, 2017-2019 (non-epidemic period) was 127.9, and the corresponding average concentrations of $\mathrm{PM}_{2.5}$, $\mathrm{PM}_{10}, \mathrm{SO}_{2}, \mathrm{CO}, \mathrm{NO}_{2}$ and $\mathrm{O}_{3}$ were $86.7 \mu \mathrm{g} \mathrm{m}^{-3}, 121 \mu \mathrm{g} \mathrm{m}^{-3}$, $5.60 \mathrm{ppb}, 0.97 \mathrm{ppm}, 47.4 \mathrm{ppb}$, and $55.1 \mathrm{ppb}$, respectively. The average AQI on the top five days with the highest AQI from January 12 to March 26, 2020 (epidemic prevention and control period) was about 83.4 , and the corresponding average concentrations of $\mathrm{PM}_{2.5}, \mathrm{PM}_{10}, \mathrm{SO}_{2}, \mathrm{CO}, \mathrm{NO}_{2}$, and $\mathrm{O}_{3}$ were $36.8 \mu \mathrm{g} \mathrm{m}^{-3}, 61.0 \mu \mathrm{g} \mathrm{m}^{-3}, 2.52 \mathrm{ppb}, 0.70 \mathrm{ppm}$, $25.4 \mathrm{ppb}$, and $50.0 \mathrm{ppb}$, which were $57.5 \%, 49.7 \%, 55 \%$, $27.1 \%, 46.3 \%$ and $9.2 \%$, lower than those in 2017-2019, respectively. In Table 2, it can be seen that the average AQI in 2020 was 83.4 , which was $34.8 \%$ lower than that of in 2017-2019 (AQI = 127.9). Compared with the same period in 2017-2019, the air quality from January 12 to March 26, 2020 improved significantly.

As shown in Table 3, in Foshan, the top five days with the highest AQIs from January 12 to March 27, 2017 were

Table 2. The top five days with the highest AQIs by year in Guangzhou from January 12 to March 27 in 2017, 2018, 2019, and 2020 .

\begin{tabular}{|c|c|c|c|c|c|c|c|}
\hline Date & AQI & $\mathrm{PM}_{2.5}\left(\mu \mathrm{g} \mathrm{m}^{-3}\right)$ & $\mathrm{PM}_{10}\left(\mu \mathrm{g} \mathrm{m}^{-3}\right)$ & $\mathrm{SO}_{2}(\mathrm{ppb})$ & $\mathrm{CO}$ (ppm) & $\mathrm{NO}_{2}(\mathrm{ppb})$ & $\mathrm{O}_{3}(\mathrm{ppb})$ \\
\hline Feb. 18, 2017 & 122 & 72.0 & 116 & 6.65 & 0.96 & 56.5 & 86.3 \\
\hline Feb. 17, 2017 & 115 & 53.0 & 91 & 6.30 & 0.88 & 55.0 & 50.4 \\
\hline Jan. 28,2017 & 114 & 88.0 & 115 & 7.35 & 0.72 & 20.0 & 60.2 \\
\hline Feb. 14, 2017 & 111 & 64.0 & 97.0 & 5.60 & 0.88 & 46.3 & 80.7 \\
\hline Mar. 3, 2017 & 109 & 60.0 & 116 & 8.05 & 0.72 & 44.8 & 79.3 \\
\hline Jan. 18, 2018 & 183 & 138 & 169 & 5.95 & 1.44 & 79.4 & 50.4 \\
\hline Feb. 16, 2018 & 180 & 136 & 146 & 7.00 & 0.80 & 24.4 & 53.2 \\
\hline Jan. 20, 2018 & 160 & 122 & 133 & 6.65 & 0.96 & 53.6 & 16.3 \\
\hline Jan. 19, 2018 & 149 & 114 & 142 & 7.35 & 1.04 & 57.5 & 38.3 \\
\hline Jan. 17,2018 & 144 & 110 & 146 & 7.00 & 1.28 & 63.8 & 55.5 \\
\hline Jan. 25, 2019 & 122 & 92.0 & 124 & 2.80 & 0.96 & 52.1 & 63.0 \\
\hline Jan. 19, 2019 & 104 & 70.0 & 117 & 3.50 & 1.12 & 42.9 & 40.1 \\
\hline Jan. 24, 2019 & 104 & 67.0 & 100 & 3.50 & 0.96 & 42.4 & 59.7 \\
\hline Mar. 12, 2019 & 101 & 54.0 & 88.0 & 3.15 & 0.88 & 32.6 & 75.1 \\
\hline Mar. 18, 2019 & 101 & 60.0 & 119 & 3.15 & 0.88 & 39.4 & 17.3 \\
\hline Feb. 23, 2020 & 92 & 37.0 & 55.0 & 2.45 & 0.64 & 19.5 & 70.0 \\
\hline Feb. 22, 2020 & 84 & 44.0 & 61.0 & 2.10 & 0.72 & 21.9 & 65.3 \\
\hline Jan. 14,2020 & 82 & 39.0 & 75.0 & 3.15 & 0.88 & 31.7 & 33.1 \\
\hline Feb. 21, 2020 & 80 & 30.0 & 46.0 & 2.10 & 0.56 & 23.4 & 63.0 \\
\hline Mar. 12, 2020 & 79 & 34.0 & 68.0 & 2.80 & 0.72 & 30.7 & 18.7 \\
\hline
\end{tabular}


on February 18, January 28, February 14, February 13, and March 3, with AQIs of 156, 118, 118, 111, and 110, respectively. On February 18, 2017, the concentrations of $\mathrm{PM}_{2.5}, \mathrm{PM}_{10}, \mathrm{SO}_{2}, \mathrm{CO}, \mathrm{NO}_{2}$, and $\mathrm{O}_{3}$ were $83.0 \mu \mathrm{g} \mathrm{m}^{-3}$, $128 \mu \mathrm{g} \mathrm{m}^{-3}, 9.10 \mathrm{ppb}, 0.80 \mathrm{ppm}, 43.3 \mathrm{ppb}$, and $103.1 \mathrm{ppb}$, respectively, and on March 3, they were $70.0 \mu \mathrm{g} \mathrm{m}^{-3}$, $125 \mu \mathrm{g} \mathrm{m}^{-3}, 8.75 \mathrm{ppb}, 0.64 \mathrm{ppm}, 39.9 \mathrm{ppb}$, and $79.8 \mathrm{ppb}$, respectively, and the indicator air pollutants for these five days were $\mathrm{O}_{3}, \mathrm{O}_{3}, \mathrm{O}_{3}, \mathrm{PM}_{2.5}$, and $\mathrm{O}_{3}$, respectively.

The top five days with the highest AQIs from January 12 to March 27, 2018 were on January 18, January 19, January 17, March 26, and January 20, with AQIs of 173, 147, 134, 132, and 124, respectively. On January 18, 2018, the concentrations of $\mathrm{PM}_{2.5}, \mathrm{PM}_{10}, \mathrm{SO}_{2}, \mathrm{CO}, \mathrm{NO}_{2}$, and $\mathrm{O}_{3}$ were $131 \mu \mathrm{g} \mathrm{m}{ }^{-3}$, $189 \mu \mathrm{g} \mathrm{m}^{-3}, 9.10 \mathrm{ppb}, 1.28 \mathrm{ppm}, 63.3 \mathrm{ppb}$, and $73.7 \mathrm{ppb}$, respectively, and on January 20 , they were $94.0 \mu \mathrm{g} \mathrm{m}^{-3}$, $153 \mu \mathrm{g} \mathrm{m}^{-3}, 7.00 \mathrm{ppb}, 0.96 \mathrm{ppm}, 48.2 \mathrm{ppb}$, and $20.5 \mathrm{ppb}$, respectively, and the indicatory air pollutants for these five days were $\mathrm{PM}_{2.5}, \mathrm{PM}_{2.5}, \mathrm{PM}_{2.5}, \mathrm{O}_{3}$ and $\mathrm{PM}_{2.5}$, respectively.

In Foshan, the top five days with the highest AQIs from January 12 to March 27, 2019, were on January 25, January 19, March 26, January 24, and February 27, with AQIs of $108,103,102,101$ and 100, respectively. On January 25, 2019 , the concentrations of $\mathrm{PM}_{2.5}, \mathrm{PM}_{10}, \mathrm{SO}_{2}, \mathrm{CO}, \mathrm{NO}_{2}$, and $\mathrm{O}_{3}$ were $81.0 \mu \mathrm{g} \mathrm{m}^{-3}, 139 \mu \mathrm{g} \mathrm{m}^{-3}, 4.20 \mathrm{ppb}, 0.96 \mathrm{ppm}$, $44.8 \mathrm{ppb}$, and $60.7 \mathrm{ppb}$, respectively, and on February 27, they were $72.0 \mu \mathrm{g} \mathrm{m}^{-3}, 149 \mu \mathrm{g} \mathrm{m}^{-3} 3.50 \mathrm{ppb}, 1.20 \mathrm{ppm}$, $34.6 \mathrm{ppb}$, and $14.0 \mathrm{ppb}$, respectively, and the indicator air pollutants for these five days were $\mathrm{PM}_{2.5}, \mathrm{NO}_{2}, \mathrm{NO}_{2}, \mathrm{NO}_{2}$, and $\mathrm{PM}_{2.5}$, respectively.

The top five days with the highest AQIs from January 12 to March 26, 2020 in Foshan, were on February 23, February 22, January 14, March 20, and March 18, with AQIs of 88, 85, 83, 82 and 72, respectively. On February
23, 2020, the concentrations of $\mathrm{PM}_{2.5}, \mathrm{PM}_{10}, \mathrm{SO}_{2}, \mathrm{CO}, \mathrm{NO}_{2}$, and $\mathrm{O}_{3}$ were $31.0 \mu \mathrm{g} \mathrm{m}^{-3}, 48.0 \mu \mathrm{g} \mathrm{m}^{-3}, 2.10 \mathrm{ppb}, 0.48 \mathrm{ppm}$, $13.6 \mathrm{ppb}$, and $67.7 \mathrm{ppb}$, respectively, and on March 18 , they were $34.0 \mu \mathrm{g} \mathrm{m}^{-3}, 57.0 \mu \mathrm{g} \mathrm{m}^{-3}, 2.10 \mathrm{ppb}, 0.64 \mathrm{ppm}$, $27.8 \mathrm{ppb}$, and $24.7 \mathrm{ppb}$, respectively, and the indicator air pollutants for these five days were $\mathrm{O}_{3}, \mathrm{O}_{3}, \mathrm{NO}_{2}, \mathrm{NO}_{2}$, and $\mathrm{NO}_{2}$, respectively.

The above results indicated that in Foshan, the average value of the 15 days with the highest AQIs from January 12 to March 27 2017-2019 (non-epidemic period) was 122.5, and the corresponding average concentrations of $\mathrm{PM}_{2.5}$, $\mathrm{PM}_{10}, \mathrm{SO}_{2}, \mathrm{CO}, \mathrm{NO}_{2}$ and $\mathrm{O}_{3}$ were $83.3 \mu \mathrm{g} \mathrm{m}^{-3}, 132 \mu \mathrm{g} \mathrm{m}^{-3}$, $6.80 \mathrm{ppb}, 0.93 \mathrm{ppm}, 40.7 \mathrm{ppb}$ and $57.7 \mathrm{ppb}$ respectively. The average AQI on the top five days with the highest AQIs from January 12 to March 262020 (epidemic prevention and control period) was approximately 82 , and the corresponding average concentrations of $\mathrm{PM}_{2.5}, \mathrm{PM}_{10}, \mathrm{SO}_{2}, \mathrm{CO}, \mathrm{NO}_{2}$, and $\mathrm{O}_{3}$ were $36.8 \mu \mathrm{g} \mathrm{m}^{-3}, 61.0 \mu \mathrm{g} \mathrm{m}^{-3}, 2.45 \mathrm{ppb}, 0.66 \mathrm{ppm}$, $24.7 \mathrm{ppb}$, and $39.2 \mathrm{ppb}$, which were $55.8 \%, 53.8 \%, 63.8 \%$, $29.3 \%, 39.2 \%$ and $32.1 \%$, lower than those in 2017-2019, respectively. In Table 3, the average AQI in 2020 was 82, which was 33\% lower than that in 2017-2019 (AQI = 122.5). Compared with the same period in 2017-2019, the air quality from January 12 to March 26, 2020 improved significantly.

Among the 60 days with the highest AQIs in the four year period under observation (2017-2020), the proportion of the number of days with the highest AQIs were $48.3 \%, 30 \%$ and $21.7 \%$ in January, February and March, respectively. It shows that the higher AQIs were mainly in January when the temperatures were lower, which was consistent with the conclusion drawn earlier that the frequency of $\mathrm{PM}_{2.5}$ as indicatory air pollutant has increased in January due to the low temperatures, and the frequency of $\mathrm{O}_{3}$ as indicatory air pollutant has increased in February and March due to the a

Table 3. The top five days with the highest AQIs by year in Foshan from January 12 to March 27 in 2017, 2018, 2019, and 2020.

\begin{tabular}{|c|c|c|c|c|c|c|c|}
\hline Date & AQI & $\mathrm{PM}_{2.5}\left(\mu \mathrm{g} \mathrm{m}^{-3}\right)$ & $\mathrm{PM}_{10}\left(\mu \mathrm{g} \mathrm{m}^{-3}\right)$ & $\mathrm{SO}_{2}(\mathrm{ppb})$ & $\mathrm{CO}(\mathrm{ppm})$ & $\mathrm{NO}_{2}(\mathrm{ppb})$ & $\mathrm{O}_{3}(\mathrm{ppb})$ \\
\hline Feb. 18, 2017 & 156 & 83.0 & 128 & 9.10 & 0.80 & 43.3 & 103.1 \\
\hline Jan. 28, 2017 & 118 & 85.0 & 104 & 5.25 & 0.56 & 12.7 & 63.9 \\
\hline Feb. 14, 2017 & 118 & 79.0 & 108 & 7.00 & 0.72 & 37.0 & 84.0 \\
\hline Feb. 13, 2017 & 111 & 83.0 & 106 & 7.00 & 0.80 & 37.0 & 58.8 \\
\hline Mar. 3, 2017 & 110 & 70.0 & 125 & 8.75 & 0.64 & 39.9 & 79.8 \\
\hline Jan. 18, 2018 & 173 & 131 & 189 & 9.10 & 1.28 & 63.3 & 73.7 \\
\hline Jan. 19, 2018 & 147 & 112 & 178 & 10.5 & 1.12 & 56.5 & 45.3 \\
\hline Jan. 17,2018 & 134 & 102 & 157 & 8.75 & 1.04 & 50.6 & 59.3 \\
\hline Mar. 26, 2018 & 132 & 57.0 & 92.0 & 4.55 & 0.72 & 19.5 & 91.0 \\
\hline Jan. 20, 2018 & 124 & 94.0 & 153 & 7.00 & 0.96 & 48.2 & 20.5 \\
\hline Jan. 25, 2019 & 108 & 81.0 & 139 & 4.20 & 0.96 & 44.8 & 60.7 \\
\hline Jan. 19, 2019 & 103 & 73.0 & 133 & 5.60 & 1.12 & 41.9 & 40.6 \\
\hline Mar. 26, 2019 & 102 & 55.0 & 102 & 5.60 & 1.04 & 40.9 & 12.1 \\
\hline Jan. 24, 2019 & 101 & 72.0 & 117 & 5.60 & 0.96 & 39.9 & 58.8 \\
\hline Feb. 27,2019 & 100 & 72.0 & 149 & 3.50 & 1.20 & 34.6 & 14.0 \\
\hline Feb. 23,2020 & 88 & 31.0 & 48.0 & 2.10 & 0.48 & 13.6 & 67.7 \\
\hline Feb. 22,2020 & 85 & 43.0 & 60.0 & 2.45 & 0.56 & 18.5 & 65.8 \\
\hline Jan. 142020 & 83 & 42.0 & 86.0 & 3.50 & 0.88 & 32.1 & 28.0 \\
\hline Mar. 20, 2020 & 82 & 34.0 & 54.0 & 2.10 & 0.72 & 31.7 & 9.8 \\
\hline Mar. 18, 2020 & 72 & 34.0 & 57.0 & 2.10 & 0.64 & 27.8 & 24.7 \\
\hline
\end{tabular}


warm temperatures. In winter, a lower ground temperature will hinder the dispersion of air pollutants and lead to an increase of $\mathrm{PM}_{2.5}$ concentration in the atmosphere in cold season. (Tang et al., 2017; Lee et al., 2018; Wang et al., 2018a). Under sufficient solar radiation intensity, $\mathrm{NO}_{2}$ acts as the precursor of photochemical reactions, and first decomposes into NO and $\mathrm{O}(3 \mathrm{P})$ :

$$
\begin{aligned}
& \mathrm{NO}_{2}+\mathrm{hv}(\lambda \leq 430 \mathrm{~nm}) \rightarrow \mathrm{NO}+\mathrm{O}\left({ }^{3} \mathrm{P}\right) \\
& \mathrm{O}\left({ }^{3} \mathrm{P}\right)+\mathrm{O}_{2} \rightarrow \mathrm{O}_{3}, \\
& \mathrm{NO}+\mathrm{O}_{3} \rightarrow \mathrm{NO}_{2}+\mathrm{O}_{2}
\end{aligned}
$$

The effect of radiation on atmospheric photochemical reactions deserves further study. When the ambient temperature is low, the three cities should pay attention to the impact of atmospheric particulates on human health.

\section{Wind Streamlines and Wind Speeds}

Fig. 5 show the distribution of the monthly average nearsurface streamlines in Guangdong Province (including Guangzhou, Foshan, and Shenzhen City) from January to March in 2019 and 2020.

Fig. 6 shows that the monthly average wind speed in this region from January to February in 2019 was generally higher than the same period in 2020, but slightly lower in March. The monthly average wind speed in January 2019 was significantly higher than that in February and March in
2019 (about 1-1.5 $\mathrm{m} \mathrm{s}^{-1}$ higher). During January to March of 2020, the monthly average wind speed in January was just slightly higher than that in February and March of 2020 (about $0.5 \mathrm{~m} \mathrm{~s}^{-1}$ higher). In terms of geographical distribution, Guangdong Province is a coastal province in southern China on the north shore of South China Sea, and the Pearl River flows through Guangdong Province from west to east and into the South China Sea in Central Guangdong.

The Pearl River Delta Region (PRD, including Guangzhou, Foshan, and Shenzhen City) is a low-lying area surrounding the Pearl River estuary. Guangzhou City is located north of the center of the PRD; Foshan City is close to the west side of Guangzhou City, and Shenzhen is located at the southeastern corner of the PRD and close to the north side of Hong Kong. During January, because of the influence of the Siberia High, the northern corner of the PRD (about 2.0$3.0 \mathrm{~m} \mathrm{~s}^{-1}$ in $2019,1.0-1.5 \mathrm{~m} \mathrm{~s}^{-1}$ in 2020 ) has relatively stronger wind speeds than the southern corner (below $1.5 \mathrm{~m} \mathrm{~s}^{-1}$ in 2019 and 2020). Until March, due to weakening of the Siberia High, the coastal region (southern corner of the PRD, below $1.5 \mathrm{~m} \mathrm{~s}^{-1}$ in $2019,2.0 \mathrm{~m} \mathrm{~s}^{-1}$ in 2020) has relatively stronger wind speeds compared to the interior region (northern corner of the PRD, below $1.0 \mathrm{~m} \mathrm{~s}^{-1}$ in $2019,1.5 \mathrm{~m} \mathrm{~s}^{-1}$ in 2020).

The distribution of the monthly average streamlines (Fig. 5) shows the places where the confluences of the streamlines generally have lower wind speed. In general, there are two main sources of airflow in Guangdong (a)

Monthly Average Streaml ines, January 2019

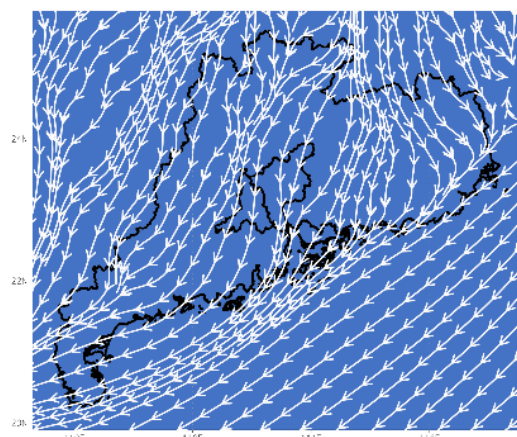

(d) Monthly Average Streamlines, January 2020

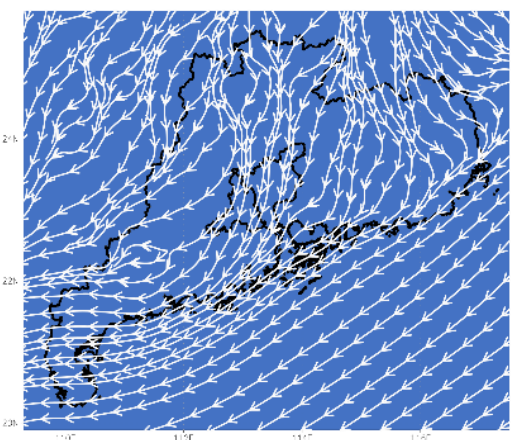

(b)



(e) Monthly Average Streamlines, February 2020

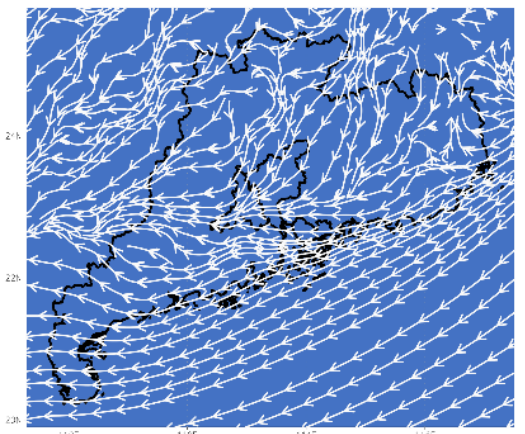

(c) Monthly Average Streamlines, March 2019

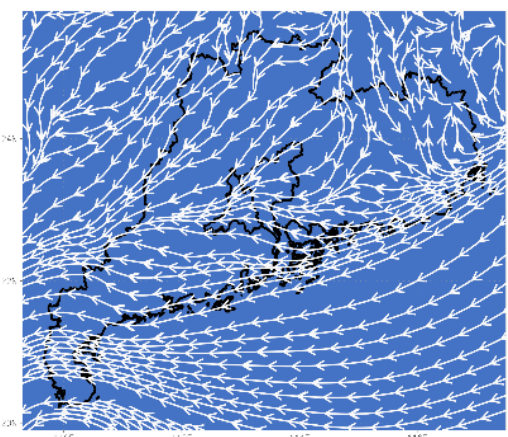

(f) Monthly Average Streamlines, March 2020

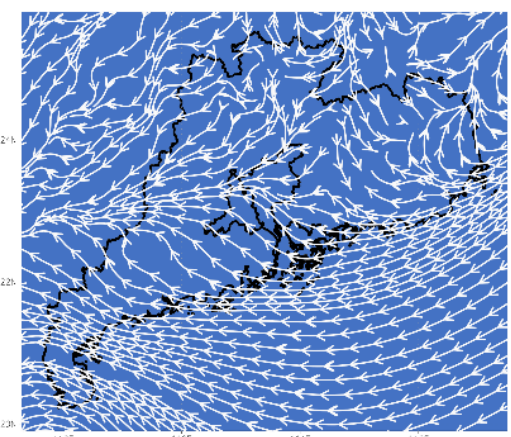

Fig. 5. NCEP GDAS/FNL 0.25 Degree Global Tropospheric Analyses data showing the distribution of the monthly average near-surface streamlines (bold white line) in Guangdong Province (including Guangzhou, Foshan, and Shenzhen City) from January to March in 2019 and 2020. 
(a)

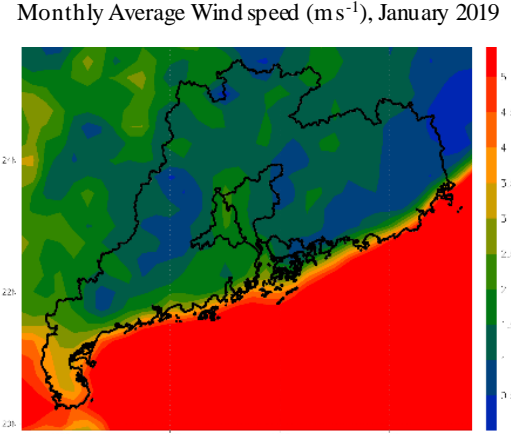

(d)

Monthly Average Wind speed $\left(\mathrm{m} \mathrm{s}^{-1}\right)$, January 2020

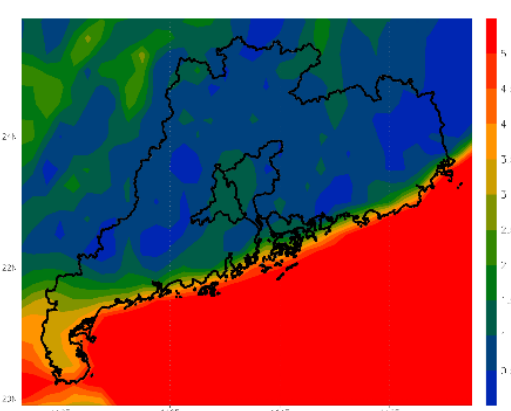

(b)

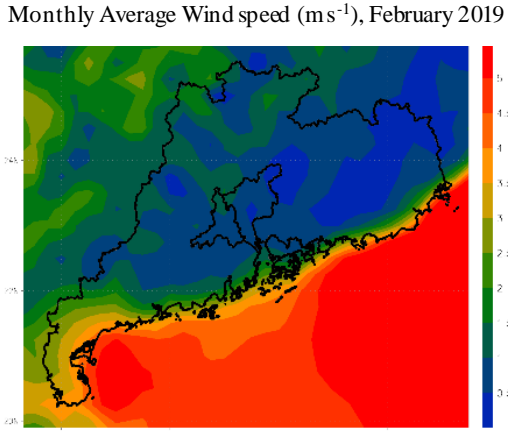

(e)

Monthly Average Wind speed $\left(\mathrm{m} \mathrm{s}^{-1}\right)$, February 2020

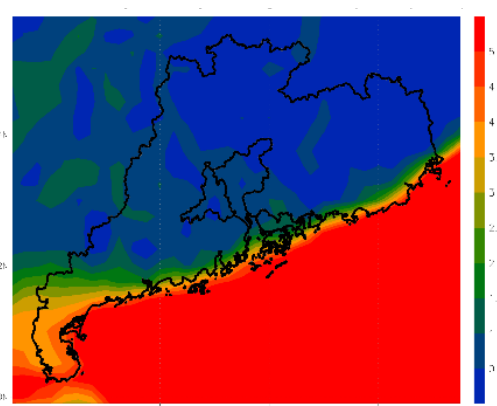

(c)

Monthly Average Wind speed $\left(\mathrm{m} \mathrm{s}^{-1}\right)$, March 2019

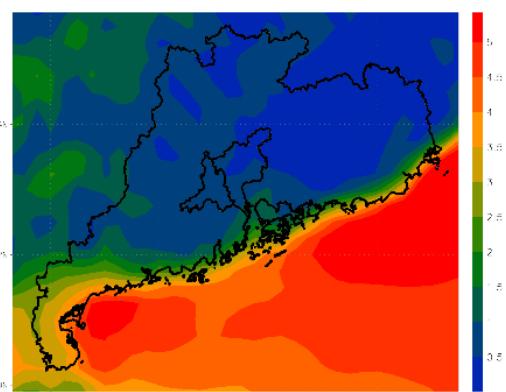

(f)

Monthly Average Wind speed $\left(\mathrm{m} \mathrm{s}^{-1}\right)$, March 2020

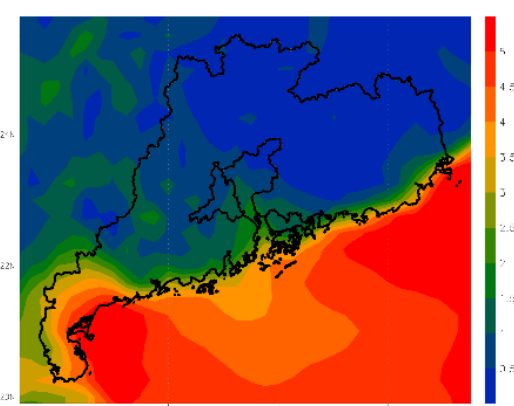

Fig. 6. NCEP GDAS/FNL 0.25 Degree Global Tropospheric Analyses data showing the distribution of the monthly average near-surface wind speed (grayscale shades, unit: $\mathrm{m} \mathrm{s}^{-1}$ ) in Guangdong Province (including Guangzhou, Foshan, and Shenzhen City) from January to March in 2019 and 2020.

Province during from January to March. One of main sources of airflow is from inland. Due to the influence of the Siberian high pressure system, the prevailing inland airflow is a northerly $(\mathrm{N})$ to northeasterly wind $(\mathrm{NE})$, which is relatively strong in January, but gradually weakens with time. The other airflow is from the ocean. The prevailing oceanic airflow is an easterly (E) to east-northeasterly wind (ENE), which is weaker in January, but gradually increases with time. In the northern PRD (Guangzhou, Foshan City), the streamlines are mainly affected by the inland airflow in January, and the prevailing wind is a northerly wind $(\mathrm{N})$ to north-northeasterly wind (NNE). From February to March, the streamlines in the northern PRD are affected by both a gradual weakening of the inland airflow and a gradually increases in the oceanic airflow. The confluence of the two airflows (inland and oceanic airflow) in the northern PRD, results in a lower wind speed in this region, making it easier to accumulate local air pollutants. During this period, Foshan is downwind of Guangzhou. In the southern PRD (Shenzhen City), from January to February, because of the confluence of the two airflows (inland and oceanic airflow), the wind speed in this region is lower, making it easier to accumulate local air pollutants. During March, the streamlines of the southern PRD are mainly affected by the oceanic airflow, and the prevailing wind is an easterly to northeasterly wind. At this time, Foshan and the south half of Guangzhou are the downwind of Shenzhen, so air pollution from Shenzhen to Guangzhou and Foshan along with the airflow.

\section{CONCLUSIONS}

1. In the combined the data from the three cities, from January 12 to March 27, in 2019, the trip intensity ranged between 0.94 and 4.82, and averaged 3.59, while those in 2020 , the trip intensity ranged between 0.73 and 5.54 , and averaged 2.57, which was $28.4 \%$ lower than that in 2019 . This indicated that the strict prevention and control measures affected the trip plans of local residents. The trip intensity in these cities remained stable around its lowest point from February 4 to February 8, 2019, while in 2020, the lowest point was between January 25 and February 9, which was due to the implementation of strict epidemic control measures in Guangdong Province has led to a reduction in the frequency of unnecessary travel.

2. As to the three cities, from January 12 to March 27 of 2019 and 2020, the average concentrations of $\mathrm{PM}_{2.5}$, $\mathrm{PM}_{10}, \mathrm{SO}_{2}, \mathrm{CO}$ and $\mathrm{NO}_{2}$ were $31.4 \mu \mathrm{g} \mathrm{m}^{-3}, 52.8 \mu \mathrm{g} \mathrm{m}^{-3}$, $2.26 \mathrm{ppb}, 0.73 \mathrm{ppm}$ and $19.1 \mathrm{ppb}$ in 2019 , and $22.7 \mu \mathrm{g} \mathrm{m}^{-3}$, $37.8 \mu \mathrm{g} \mathrm{m}^{-3}, 2.00 \mathrm{ppb}, 0.56 \mathrm{ppm}$ and $13.6 \mathrm{ppb}$ in 2020 , which were $27.7 \%, 28.5 \%, 11.8 \%, 22.9 \%$ and $29.1 \%$ lower than those in 2019, respectively. During the epidemic control period, restrictions on industrial production and mobile transportation resulted in reduction the average concentrations of $\mathrm{PM}_{2.5}, \mathrm{PM}_{10}, \mathrm{SO}_{2}, \mathrm{CO}$ and $\mathrm{NO}_{2}$. However, the average $\mathrm{O}_{3}$ concentration (35.2 ppb) from January 12 to March 26, 2020 did not show a significant decrease, but rather increased by $8.4 \%$. This is because 
the concentration of $\mathrm{NO}_{2}$ in the atmosphere is low, the conditions are not conductive to the $\mathrm{NO}+\mathrm{O}_{3}$ reaction, resulting in a low $\mathrm{O}_{3}$ reaction rate. Due to atmospheric pollutants from monsoon transportation and normal operation of power plants, the atmospheric pollutant concentrations corresponding to the same trip intensity were higher in 2020 than in 2019.

3 . For the combined AQIs for the three cities, from January 12 to March 27, 2019 the daily AQIs ranged between 21.0 and 121.3 and averaged 56.4; from January 12 to March 26, 2020 the daily AQIs ranged between 18.0 and 91.7 and averaged 47.4, which was $16.0 \%$ lower than in 2019. From January 12 to March 27, 2019 the distributions of the six AQI classes were 45.2\%, 50.4\%, 4.4\%, 0\%, 0\%, and $0 \%$, respectively; in 2020 were $62.7 \%, 37.3 \%, 0 \%$, $0 \%, 0 \%$, and $0 \%$, respectively. It shows that from January 12 to March 26, 2020, the air quality near southern China improved significantly.

4. For the combined data of three cities, on the top 5 days with the highest AQIs during the epidemic period (from January 12 to March 26, 2020), the average concentrations of $\mathrm{PM}_{2.5}, \mathrm{PM}_{10}, \mathrm{SO}_{2}, \mathrm{CO}, \mathrm{NO}_{2}$, and $\mathrm{O}_{3}$ were $76.4 \mu \mathrm{g} \mathrm{m}^{-3}$, $113.4 \mu \mathrm{g} \mathrm{m}^{-3}, 5.14 \mathrm{ppb}, 0.88 \mathrm{ppm}, 36.5 \mathrm{ppb}$, and $55.5 \mathrm{ppb}$, which were $55.2 \%, 49.4 \%, 55.1 \%, 30.0 \%, 45.1 \%$, and $15.5 \%$ lower than those during the non-epidemic period (from January 12 to March 27, 2017-2019). From January 12 to March 27, 2017-2019, the AQI on the five highest days averaged 170, while that in 2020 averaged 86.4, which was $49.2 \%$ lower than that during the non-epidemic period (2019). Compared with the same period in 20172019, the air quality from January 12 to March 26, 2020 has improved significantly.

5. In general, in Shenzhen City, from January to February (2019-2020), because of the confluence of the two types of airflow (inland and oceanic airflow), the lower wind speed in this region made it easier to accumulate local air pollutants. During March, Foshan and the south half of Guangzhou were downwind of Shenzhen, so air pollution could be transported from Shenzhen to Guangzhou and Foshan along with the airflow. The wind streamline and wind speed data provide a theoretical basis for the transportation of air pollutants and their impact on the surrounding environment.

\section{REFERENCES}

Ajelli, M., Goncalves, B., Balcan, D., Colizza, V., Hu, H., Ramasco, J.J., Merler, S. and Vespignani, A. (2010). Comparing large-scale computational approaches to epidemic modeling: Agent-based versus structured metapopulation models. BMC Infect. Dis. 10: 190-190. https://doi.org/10.1186/1471-2334-10-190

Anderson, R.M., Heesterbeek, H., Klinkenberg, D. and Hollingsworth, T.D. (2020). How will country-based mitigation measures influence the course of the COVID19 epidemic? Lancet 395: 931-934. https://doi.org/10.10 16/S0140-6736(20)30567-5

Atri, D., Siddiqi, H.K., Lang, J., Nauffal, V. and Bohula, E.A. (2020). COVID-19 for the cardiologist: A current review of the virology, clinical epidemiology, cardiac and other clinical manifestations and potential therapeutic strategies. JACC Basic Transl. Sci. 5: 518-536. https://doi.org/10.1016/j.jacbts.2020.04.002

Bashir, M.F., Ma, B., Bilal, D., Komal, B. and Bashir, M. (2020). Correlation between climate indicators and COVID-19 pandemic in New York, USA. Sci. Total Environ. 728: 138835-138843. https://doi.org/10.1016/j. scitotenv.2020.138835

Bowman, F.M. and Seinfeld, J.H. (1994). Ozone productivity of atmospheric organics. J. Geophys. Res. 99: 5309-5324. https://doi.org/10.1029/93JD03400

Cao, J., Xu, H., Xu, Q., Chen, B. and Kan, H. (2012). Fine Particulate Matter constituents and cardiopulmonary mortality in a heavily polluted Chinese city. Environ. Health Perspect. 120: 373-378. https://doi.org/10.1289/ ehp.1103671

Chan, C.K. and Yao, X. (2008). Air pollution in mega cities in China. Atmos. Environ. 42: 1-42. https://doi.org/10.10 16/j.atmosenv.2007.09.003

Chen, B., Lu, S.W., Li, S.N. and Wang, B. (2015). Impact of fine particulate fluctuation and other variables on Beijing's air quality index. Environ. Sci. Pollut. Res. 22: 5139-5157. https://doi.org/10.1007/s11356-014-4024-z

Cheng, N.L., Li, Y.T., Sun, F., Chen, C., Wang, B.Y., Li, Q., Wei, P. and Cheng, B.F. (2018). Ground-Level $\mathrm{NO}_{2}$ in urban Beijing: Trends, distribution, and effects of emission reduction measures. Aerosol Air Qual. Res. 18: 343-356. https://doi.org/10.4209/aaqr.2017.02.0092

Clapp, L.J. and Jenkin, M.E. (2001). Analysis of the relationship between ambient levels of $\mathrm{O}_{3}, \mathrm{NO}_{2}$ and $\mathrm{NO}$ as a function of $\mathrm{NO}_{\mathrm{x}}$ in the UK. Atmos. Environ. 35: 63916405. https://doi.org/10.1016/S1352-2310(01)00378-8

Dentener, F., Kinne, S., Bond, T.C., Boucher, O., Cofala, J., Generoso, S., Ginoux, P., Gong, S.L., Hoelzemann, J.J. and Ito, A. (2006). Emissions of primary aerosol and precursor gases in the years 2000 and 1750, prescribed data-sets for AeroCom. Atmos. Chem. Phys. 6: 43214344. https://doi.org/10.5194/acp-6-4321-2006

Halmer, M.M., Schmincke, H. and Graf, H. (2002). The annual volcanic gas input into the atmosphere, in particular into the stratosphere: A global data set for the past 100 years. J. Volcanol. Geotherm. Res. 115: 511528. https://doi.org/10.1016/S0377-0273(01)00318-3

Heal, M.R., Kumar, P. and Harrison, R.M. (2012). Particles, air quality, policy and health. Chem. Soc. Rev. 41: 66066630. https://doi.org/10.1039/c2cs35076a

Holshue, M.L., DeBolt, C., Lindquist, S., Lofy, K.H., Wiesman, J. and Bruce, H. (2020). First case of 2019 novel coronavirus in the United States. N. Engl. J. Med. 382: 143-153. https://doi.org/10.1056/NEJMoa2001191

Hu, J.L., Ying, Q., Wang, Y.G. and Zhang, H.L. (2015). Characterizing multi-pollutant air pollution in China: Comparison of three air quality indices. J. Environ. Int. 15: 17-25. https://doi.org/10.1016/j.envint.2015.06.014

Jin, L., Luo, X.S., Fu, P.Q. and Li, X.D. (2017). Airborne particulate matter pollution in urban China: A chemical mixture perspective from sources to impacts. Nat. Sci. Rev. 4: 593-610. https://doi.org/10.1093/nsr/nww079 
Kato, S., Shiobara, Y., Uchiyama, K., Miura, K., Okochi, H., Kobayashi, H. and Hatakeyama, S. (2016). Atmospheric $\mathrm{CO}, \mathrm{O}_{3}$, and $\mathrm{SO}_{2}$ measurements at the summit of Mt. Fuji during the summer of 2013. Aerosol Air Qual. Res. 16: 2368-2377. https://doi.org/10.4209/aaqr.2015.11.0632

Kettle, A.J. and Andreae, M.O. (2000). Flux of dimethylsulfide from the oceans: A comparison of updated data sets and flux models. J. Geophys. Res. 105: 26793-26808. https://doi.org/10.1029/2000JD900252

Khattak, P., Khokhar, M.F. and Khan, S.A. (2013). Transboundary volcanic $\mathrm{SO}_{2}$ detected over Pakistan from satellite observations during the time period 2004-2012. Aerosol Air Qual. Res. 14: 1543-1557. https://doi.org/10. 4209/aaqr.2013.12.0361

Kleinman, L.I. (2005). The dependence of tropospheric ozone production rate on ozone precursors. Atmos. Environ. 39: 575-586. https://doi.org/10.1016/j.atmosenv.2004.08.047

Kyrkilis, G., Chaloulakou, A. and Kassomenos, P.A. (2007). Development of an aggregate Air Quality Index for an urban Mediterranean agglomeration: Relation to potential health effects. Environ. Int. 33: 670-676. https://doi.org/10.1016/j.envint.2007.01.010

Lal, S., Naja, M. and Subbaraya, B.H. (2000). Seasonal variations in surface ozone and its precursors over an urban site in India. Atmos. Environ. 34: 2713-2724. https://doi.org/10.1016/S1352-2310(99)00510-5

Lanzafame, R., Monforte, P., Patane, G and Strano, S. (2015). Trend analysis of air quality index in Catania from 2010 to 2014. Energy Procedia. 82: 708-715. https://doi.org/10.1016/j.egypro.2015.11.796

Lee, C., Richter, A., Weber, M. and Burrows, J.P. (2008). $\mathrm{SO}_{2}$ Retrieval from SCIAMACHY using the Weighting Function DOAS (WFDOAS) technique: Comparison with Standard DOAS retrieval. Atmos. Chem. Phys. 8: 6137-6145. https://doi.org/10.5194/acp-8-6137-2008

Lee, Y.Y., Wang, L.C., Zhu, J.N., Wu, J.L. and Lee, K.L. (2018). Atmospheric $\mathrm{PM}_{2.5}$ and polychlorinated dibenzo$p$-dioxins and dibenzofurans in Taiwan. Aerosol Air Qual. Res. 18: 762-779. https://doi.org/10.4209/aaqr.20 18.02.0050

Lee, Y.Y., Hsieh, Y.K., Chang-Chien, G.P. and Wang, W.W. (2019). Characterization of the Air Quality Index in Southwestern Taiwan. Aerosol Air Qual. Res. 19: 749785. https://doi.org/10.5194/acp-8-6137-2008

Liang, D., Wang, Y.Q., Ma, C. and Wang, Y.J. (2016). Variability in transport pathways and source areas of $\mathrm{PM}_{10}$ in Beijing during 2009-2012. Aerosol Air Qual. Res. 16: 3130-3141. https://doi.org/10.4209/aaqr.2016.02.0090

Matus, K.J.M., Nam, K., Selin, N.E., Lamsal, L.N., Reilly, J.M. and Paltsev, S. (2012). Health damages from air pollution in China. Global Environ. Change 22: 55-66. https://doi.org/10.1016/j.gloenvcha.2011.08.006

Myhre, G. (2009). Consistency between satellite-derived and modeled estimates of the direct aerosol effect. Science 325: 187-190. https://doi.org/10.1126/science.1174461

Perlman, S. (2020). Another decade, another coronavirus. N. Engl. J. Med. 382: 760-762. https://doi.org/10.1056/N EJMe2001126

Pope, C. and Dockery, D. (2006). Health effects of fine particulate air pollution: Lines that connect. J. Air Waste Manage. Assoc. 56: 709-742. https://doi.org/10.1080/10 473289.2006.10464485

Pope, C.A. and Dockery, D.W. (2013). Air pollution and life expectancy in China and beyond. Proc. Natl. Acad. Sci. U.S.A. 110: 12861-12862. https://doi.org/10.1073/p nas. 1310925110

Querol, X., Alastuey, A., Ruiz, C., Artinano, B., Hansson, H., Harrison, R.M., Buringh, E., Brink, H.M.T., Lutz, M. and Bruckmann, P. (2004). Speciation and origin of $\mathrm{PM}_{10}$ and $\mathrm{PM}_{2.5}$ in selected European cities. Atmos. Environ. 38: 6547-6555. https://doi.org/10.1016/j.atmosenv.2004. 08.037

Samet, J.M., M.D., Dominici, F., Curriero, F.C., Coursac, I. and Zeger, S. (2000). Fine particulate air pollution and mortality in 20 U.S. cities. N. Engl. J. Med. 343: 19871994. https://doi.org/10.1056/NEJM200012143432401

She, Q.N., Peng, X., Xu, Q., Long, L.B., Wei, N. Liu, M. and Jia, W.X. (2017). Air quality and its response to satellite-derived urban form in the Yangtze River Delta, China. Environ. Res. Sci. 75: 297-306. https://doi.org/10. 1016/j.ecolind.2016.12.045

Shen, F.Z., Ge, X.L., Hu, J.L., Nie, D.Y., Tian, L. and Chen, M.D. (2017). Air pollution characteristics and health risks in Henan Province, China. Environ. Res. Sci. 156: 625-634. https://doi.org/10.1016/j.envres.2017.04.026

Song, Y., Miao, W., Liu, B., Dai, W. and Cai, X. (2008). Identifying anthropogenic and natural influences on extreme pollution of respirable suspended particulates in Beijing using backward trajectory analysis. J. Hazard. Mater. 154: 459-468. https://doi.org/10.1016/j.jhazmat.2 007.10 .064

Sun, Y., Jiang, Q., Wang, Z., Fu, P., Li, J., Yang, T. and Yin, Y. (2014). Investigation of the sources and evolution processes of severe haze pollution in Beijing in January 2013. J. Geophys. Res. 119: 4380-4398. https://doi.org/ 10.1002/2014JD021641

Tang, H.Y., Cui, K.P., Xing, J., Zhu, J.N., Lee, W.J., John, K.M. and Lee, Y.C. (2017). Part I: $\mathrm{PM}_{2.5}$ and polychlorinated dibenzo- $p$-dioxins and dibenzofurans (PCDD/Fs) in the ambient air of southern China. Aerosol Air Qual. Res. 17: 1550-1569. https://doi.org/10.4209/a aqr.2017.03.0117

Tao, J., Ho, K.F., Chen, L., Zhu, L., Han, J. and Xu, Z. (2009). Effect of chemical composition of $\mathrm{PM}_{2.5}$ on visibility in Guangzhou, China, 2007 spring. Particuology 7: 6875. https://doi.org/10.1016/j.partic.2008.11.002

Vingarzan, R. (2004). A review of surface ozone background levels and trends. Atmos. Environ. 38: 3431-3442. https://doi.org/10.1016/j.atmosenv.2004.03.030

Wang, W.W., Cui, K.P., Zhao, R., Hsieh, L.T. and Lee, W.J. (2018). Characterization of the air quality index for Wuhu and Bengbu cities, China. Aerosol Air Qual. Res. 18: 1198-1220. https://doi.org/10.4209/aaqr.2018.04.0135

Wu, X.H., Huang, W.W., Zhang, Y.X., Zheng, C.H., Jiang, X., Gao, X. and Cen, K.F. (2015). Characteristics and uncertainty of industrial VOCs emissions in China. Aerosol Air Qual. Res. 15: 1045-1058. https://doi.org/1 0.4209/aaqr.2014.10.0236 
Xu, G., Jiao, L., Zhang, B., Zhao, S., Yuan, M., Gu, Y., Liu, J. and Tang, X. (2017). Spatial and temporal variability of the $\mathrm{PM}_{2.5} / \mathrm{PM}_{10}$ ratio in Wuhan, Central China. Aerosol Air Qual. Res. 17: 741-751. https://doi.org/10.4209/aaqr. 2016.09.0406

Xu, K.J., Cui, K.P., Young, L.H., Hsieh, Y.K., Wang, Y.F., Wan, S. and Zhang, J.J. (2020a). Impact of the COVID19 event on air quality in central China. Aerosol Air Qual. Res. 20: 915-929. https://doi.org/10.4209/aaqr.2020.04. 0150

Xu, K.J., Cui, K.P., Young, L.H., Hsieh, Y.K., Wang, Y.F., Wan, S. and Zhang, J.J. (2020b). Air quality index, indicatory air pollutants and impact of COVID-19 event on the air quality near central China. Aerosol Air Qual. Res. 20: 1204-1221. https://doi.org/10.4209/aaqr.2020.0 4.0139
Zhang, J., Cui, K., Wang, Y.F., Wu, J.L., Huang, W.S., Wan, S. and Xu, K. (2020). Temporal variations in the air quality index and the impact of the COVID-19 event on air quality in Western China. Aerosol Air Qual. Res. 20: 1552-1568. https://doi.org/10.4209/aaqr.2020.06.0297

Zhao, R., Cui, K.P., Wang, W.W., Wang, L.C. and Yan, P. (2018). Atmospheric $\mathrm{PM}_{2.5}$ and total PCDD/Fs-WHO $\mathrm{WH}_{205}$ TEQ level: A case of Handan and Kaifeng cities, China. Aerosol Air Qual. Res. 18: 994-1007. https://doi.org/10. 4209/aaqr.2018.02.0040

Received for review, July 1, 2020

Revised, July 22, 2020

Accepted, July 22, 2020 